\title{
ŻYCIE SAKRAMENTALNE I PARALITURGICZNE W DIECEZJI KRAKOWSKIEJ W OKRESIE RZĄDÕW KARD. J. A. LIPSKIEGO (1732-1746)
}

Opracowanie niniejsze przedstawia życie sakramentalne wiernych w parafiach w diecezji krakowskiej w ciągu 14 lat rządów biskupich kard. Jana Aleksandra Lipskiego (1732-1746). Omawia ono szeroko

* Poniższy artykuł jest fragmentem rozprawy doktorskiej pt. Działalność duszpasterska biskupa Jana Aleksandra kardynala Lipskiego $w$ diecezji krakowskiej $w$ latach 1732-1746. Promotorem pracy był prof. dr hab. Bolesław Kumor. Przewód doktorski Autora odbył się w r. 1984 na Wydziale Teologicznym Papieskiej Akademii Teologicznej w Krakowie.

W przypisach zastosowano następujące skróty:
AEp
- Acta episcopalia.
AKM - Archiwum Kapituty Metropolitalnej w Krakowie.
AKMKr - Archiwum Kurii Metropolitalnej w Krakowie.
AOf
AP
- Acta officialia.
CSM
- Archiwum parafii.
$\begin{array}{ll} & \text { Wężyk editae, Cracoviae reimpressae } 1761 . \\ \text { ELip } & - \text { J. A. Li p s ki, Epistola pastoralis [...], Cracoviae } 1737 .\end{array}$
EMac - Epistola pastoralis Macieioviana [...] reimpressa 1720.
$\mathrm{ESz}$ - C. F. Szaniawski, Epistola pastoralis [...], Cracoviae 1720.
RGSz - Reformationes Generales [...] ab Martino Szyszkowski [...] episcopo Cracoviensi [...] in synodo promulgata 1621.
SŁ - Synodus dioecesana [...] ab Casimiro Eubieński [...] episcopo Crac. ce- lebrata 1711.
Vis. 24 - Status ecclesiarum ac illorum rectorum sub decanatu Ecclesiae Collegiatae Kielcensis alias in tribus decanalibus: Radomiensi, Zwo- lensi et Stężycensi [...] per visitationem generalem. A. D. 1736, vol. 24.
Vis. 25 - Visitatio Archidiaconatus Sandomiriensis scilicet quatuor decanatuum: Coprivnicensis, Polanecensis, Rudnicensis et Michocinensis per me Andream Potocki 1736-1738, vol. 25.
Vis. 26 - Visitatio decanatus Leloviensis [...] ad praepositum Pilecensem spe- ctans [...] per D. Adamum I. Komorowski [...] expedita 1739, vol. 26.
Vis. 27 - Visitatio interna et externa ecclesiarum, praeposituralium, parochia- lium, hospitalium aliorum beneficiorum in decanalibus Bodzentinen- sis, Kunoviensis consistentium per me Venceslaum H. de Bogusta- wice Sierakowski peracta 1738-1739, vol. 27. 
i gruntownie przepisy normatywne tegoż biskupa oraz wysiłek duszpasterzy, by wskazania te realizować w swoich parafiach. Takie ujęcie zagadnienia $\mathrm{w}$ małym stopniu uwzględnia zaangażowanie wiernych w omawianych przez nas problemach i pomija skuteczność praktyk sakramentalnych w ich życiu codziennym; jest to spowodowane brakiem przekazów źródłowych na ten temat.

Warto również wspomnieć, że rozporządzenia bpa Lipskiego dotyczące życia sakramentalnego miały swoje źródło w ustawodawstwie synodalnym prowincji kościelnej gnieźnieńskiej. Można więc przypuszczać, że życie sakramentalne wiernych w diecezji krakowskiej prawdopodobnie miało podobny charakter w całej Rzeczypospolitej przedrozbiorowej.

Trzeba podkreślić, że bp Lipski, jako rządca diecezji krakowskiej, decydował o formach szafarstwa sakramentów świętych, działając zgodnie z nauką Soboru Trydenckiego i nakazami polskich synodów prowincjalnych.

W duchu tej odpowiedzialności w liście pasterskim z roku 1737 podał najpierw ogólne wskazania co do szafarstwa sakramentów, a następnie omawiał liturgię poszczególnych sakramentów.

Sakramenty nazwał „,naczyniami zbawienia”, „symbolami łaski”, które nie tylko łaskę oznaczają, lecz także udzielają jej godnie do nich przystępującym. Sakramenty winny być z czystym sercem przyjmowane, gdyż od tego zależy ich skuteczność. Kapłani powinni pamiętać, by „,́więte święcie traktować”, a w szafarstwie sakramentów mieć specjalną dbałość, by z powodu zaniedbań „Bóg nie zażądał od nich krwi za dusze ludzkie”. „Pomni na swoje szczególne powołanie do zbawienia dusz - pisał dalej bp Lipski — gdy będą wezwani, powinni o każdej porze dnia i nocy chętnie i jak najszybciej pobożnie udzielać świętych posług, pobudzając do pobożności wszystkich obecnych". Przypominał duchownym, że ,darmo otrzymali, darmo mają dawać”, nic za posługi duchowne nie żądać ani prosić, zadowalając się dobrowolnymi ofiarami. Ze względu na szacunek dla świętych obrzędów napominał szafarzy do przestrzegania $\mathrm{z}$ całą pobożnością i dokładnością przepisów liturgicznych i ceremonii ${ }^{1}$.

Po tym ogólnym wprowadzeniu przypatrzmy się szafarstwu poszczególnych sakramentów świętych za rządów bpa Lipskiego w 1 . połowie XVIII wieku w diecezji krakowskiej.

1 ELip: De administratione sacramentorum. 


\section{CHRZEST}

Chrzest jest początkiem i źródłem życia chrześcijańskiego i życia Bożego w człowieku. Dlatego synody prowincjalne polskie potrydenckie, a. zwłaszcza synod prowincjalny z r. 1628, nakazywały z wielką czcią i szacunkiem udzielać tego sakramentu ${ }^{2}$. Biskupi krakowscy przypominali duchowieństwu i wiernym pouczenia synodów prowincjalnych na synodach diecezjalnych w r. 1621 i 1711 oraz w listach biskupich. Równięż bp Lipski w liście pasterskim poświęcił temu sakramentowi czwarty rozdział.

Do tegoż sakramentu przywiązywał on ogromną wagę, dlatego pisał, że dbałość o sprawowanie chrztu winni mieć wszyscy kapłani diecezji krakowskiej. Powoływał się przy tym na naukę Kościoła, sformułowaną przez Sobór Trydencki ${ }^{3}$. Stwierdził, że chrzest jest sakramentem wiary, bez którego nie można się zbawić. Skoro jest konieczny do zbawienia, to należy go pilnie, ochotnie, $\mathrm{z}$ należną czcią i uwagą udzielać. Kapłanów czynił odpowiedzialnymi za to, by dzieci nie umierały bez chrztu świętego. Polecał, by proboszczowie sami chrzcili i pouczali wszystkich, a zwłaszcza niewiasty, o intencji, formie i materii sakramentu chrztu, by umiano go udzielać w wypadku niebezpieczeństwa śmierci. Dzieci ochrzczone przez akuszerki czy inne niewiasty należało przynosić do kościoła w celu uzupełnienia obrzędów liturgicznych. W wypadku wątpliwości co do ważności chrztu należało taki przypadek roztropnie rozważyć i ewentualnie ochrzcić dziecko warunkowo. Miejscem udzielania sakramentu chrztu winien być kościół i dlatego zabraniał chrzcić $\mathrm{w}$ prywatnych domach, $\mathrm{z}$ wyjątkiem niebezpieczeństwa śmierci dziecka lub na specjalne zezwolenie władz duchownych.

Dalsze wskazówki dotyczyły rodziców chrzestnych. Należało ich pouczyć, że przy chrzcie powstaje między nimi a chrzczonym przeszkoda pokrewieństwa duchowego, która uniemożliwiała zawarcie ważnego małżeństwa między tymi osobami. Przeszkoda ta zachodziła tylko między pierwszą parą rodziców chrzestnych a dzieckiem. Bp Lipski nakazywał akt chrztu zapisać $\mathrm{w}$ księgach metrykalnych. Zapis ten obejmował dzień i rok chrztu, imię chrzczonego, imiona jego rodziców i imiona rodziców chrzestnych ${ }^{4}$. Do pouczenja tego bp Lipski nie dołączył wskazówek pastoralnych.

Nie znajdujemy również wskazówek na temat, kiedy rodzice powinni przynosić dzieci do chrztu - czy zaraz po urodzeniu, czy później. Pi-

2 Synodus prov. Gnesn. [...] sub Joanne Wężyk [...] Petricoviae A. D. 1628 celebrata: De baptismo, s. 33 .

${ }^{3}$ RGSz: De baptisimi sacramento, s. 66; ESz: De baptismo.

4 ELip: De baptismo. 
sząc o rodzicach chrzestnych nie wymagał znajomości prawd wiary ani specjalnych pouczeń. Również nie wspominał o imionach nadawanych dzieciom na chrzcie. Nasuwa się pytanie, jak w duszpasterstwie diecezjalnym praktykowano wówczas udzielanie chrztu świętego. Można $\mathrm{z}$ całą pewnością powiedzieć, że duszpasterze mieli wielkie zrozumienie dla tego sakramentu. Chrzcili przynoszone dzieci o każdej porze dnia i nocy. Potwierdzają to wizytacje, w których nie ma nigdzie notatki o zaniedbaniach $\mathrm{w}$ tym zakresie ${ }^{5}$. Metryki chrztów parafii wiejskich (w Tenczynku ', w Szaflarach ${ }^{7}$, w Łazanach $^{8}$ ) i miejskich (Najśw. Maryi Panny ${ }^{\circ}$, Wszystkich Swiętych $\mathrm{w}_{\text {Krakowie }}{ }^{10}$, Sw. Jakuba na Kazimierzu ${ }^{11}$ ) poświadczają, że zazwyczaj chrzczono dzieci w dniu urodzenia. Jedynie dzieci szlacheckie przynoszono do chrztu w kilka dni czy nawet miesięcy po urodzeniu. Trafiały się również chrzty ludzi dorosłych w przypadkach konwersji (np. w parafii mariackiej w Krakowie od r. 1732 do 1746 było takich chrztów 105, przeważnie żydów).

Miejscem chrztu był kościół parafialny, a w przypadku udzielania go w domu traktowano chrzest jako obrzęd niekompletny i zawsze ceremonię uzupełniano $\mathrm{w}$ kościele. Do chrztu używali kapłani wody chrzcielnej, poświęcanej w Wielką Sobotę, a przechowywanej w chrzcielnicy. Wizytatorzy sprawdzali w każdej parafii, jak proboszczowie przestrzegali przepisów Rytuału rzymskiego z r. 1614 w jego wydaniu piotrkowskim (1631) w zakresie przyozdobienia, czystości, a zwłaszcza zamykania chrzcielnic ${ }^{12}$. Trzeba stwierdzić, że w większości przypadków $\mathrm{w}$ wizytowanych parafiach duszpasterze dbali o chrzcielnice. W dekanacie bodzentyńskim, kunowskim, koprzywnickim, lelowskim i rudnickim wszystkie chrzcielnice były czyste, woda wymieniana i poświęcana, przykrycia przyozdobione i zamykane ${ }^{13}$. Zaniedbane chrzcielnice znaleźli wizytatorzy $\mathrm{w}$ dekanacie stężyckim (6 nie zamykanych $\left.{ }^{14}\right)$, zwo-

5 M. Laskowski, Życie liturgiczne $w$ parafiach dekanatu kazimierskiego $w$ XVIII wieku $w$ świetle akt wizytacji biskupich, [w:] Studia $z$ dziejów liturgii $w$ Polsce, pod red. W. S chenka, t. 3, Lublin 1980, s. 94; E. J a nick a, Praktyki religijne $w$ archidiakonacie lubelskim $w$ XVIII w., Lublin 1964 (KUL - maszynopis), s. 24; J. Kracik, Duszpasterstwo parafialne $w$ dekanacie Nowa Góra $w$ pierwszej połowie XVIII w., [w:] Studia kościelno-historyczne, t. 2, Lublin 1977, s. 229 (przypis 15), s. 256.

6 AP Tenczynek: Liber baptisatorum 1661-1701.

7 AP Szaflary: Metrica baptisatorum 1738-1746.

8 AP Eazany: Liber baptisatorum 1732-1746, s. 186-218.

9 Archiwum Archiprezbiterialnego kościoła N.M. Panny w Krakowie: Metrica baptisatorum ab 1714-1737, s. 183-641; ab 1738, s. 1-177.

10 AP Wszystkich Swiętych w Krakowie: Liber baptisatorum ab 1730-1739.

11 AP Bożego Ciała w Krakowie: Liber baptisatorum.

12 Rituale sacramentorum, Cracoviae 1743, s. 1-20; W. S chenk, Liturgia sakramentów św., t. 1, Lublin 1962, s. 44 n.

18 AKMKr: Vis. 27/38; Vis. 26/39; Vis. 25/36.

14 AKMKr: Vis. 24, s. 248 (Stężyca); s. 290 (Wilczysko); s. 294 (Żelechów); s. 275 (Korytnica); s. 310 (Ryki); s. 329 (Drzązgów). 
leńskim ( 5 nie zamykanych ${ }^{15}$ ), radomskim ( 2 bez zamknięcia ${ }^{10}$ ) i połanieckim (tylko jedna nie zamykana ${ }^{17}$ ). Na 133 wizytowane parafie w 14 parafiach wizytatorzy zauważyli brak dbałości o chrzcielnice, co stanowi $11 \%$ całości. Najgorzej było w Brzózie w dekanacie zwoleńskim, gdzie wizytator zauważył, że ,chrzcielnica przez niedbałość zawsze otwarta i niezamknięta pozostaje" ${ }^{18}$. We Wsole w dekanacie radomskim woda w chrzcielnicy była zaśmiecona, nie zamknięta ${ }^{19}$.

$\mathrm{Na}$ wybór imienia dawanego dziecku wpływało wiele czynników. Potwierdzają się tu wyniki badań historycznych nad obyczajami w dawnej Polsce ${ }^{20}$. Dokładne przebadanie wspomnianych ksiąg metrykalnych przekonuje mnie, że decydującym czynnikiem był dzień i miesiąc urodzenia dziecka; stosowano praktykę, że dziecko „,przynosiło” sobie imię. $\mathrm{Na}$ chrzestnych proszono krewnych, sąsiadów, z zachowaniem przynależności do danego stanu. Wiadomo również, że np. w dekanacie nowogórskim często proszono na rodziców chrzestnych organistę, proboszcza, a nawet żebraków ${ }^{21}$.

$\mathrm{Na}$ zakończenie wypada jeszcze wspomnieć o obrzędzie błogosławieństwa matek $\mathrm{z}$ okazji urodzenia dziecka. Bp Lipski nie wspomina o tym obrzędzie, ale nakazywał go Rytuał piotrkowski z r. 1631. Z opracowań tematu wiadomo, że matki-chłopki i matki-mieszczanki w diecezji krakowskiej przychodziły najczęściej w ósmym dniu od urodzenia dziecka do ,wywodu".

\section{BIERZMOWANIE}

Teologowie-liturgiści widzą taki związek między chrztem a bierzmowaniem, jak między Wielkanocą a Zielonymi Swiętami. Ponieważ te ostatnie są dopełnieniem tajemnicy wielkanocnej, tak samo i sakrament bierzmowania jest dopełnieniem chrztu świętego. Jeżeli przez chrzest człowiek staje się świątynią Boga, to bierzmowanie jest konsekracją tej świątyni. W okresie potrydenckim sakrament ten nie był zbyt doceniany także w Polsce ${ }^{22}$. Podobnie bp Lipski nie doceniał zna-

15 AKMKr: Vis. 24, s. 137 (Odechów); s. 172 (Sucha); s. 186 (Brzoza); s. 206 (Swierze); s. 222 (Policzna).

${ }_{16}$ AKMKr: Vis. 24, s. 124 (Wsola); s. 36 (Kowalska Wola).

17 AKMKr: Vis. 25, s. 140 (Strzyżowice).

18 "Fons per negligentiam semper apertus et non clausus manet" (AKMKr: Vis. 24, s. 186 - Brzoza).

${ }_{19}$ "Quisquillarum plena in labete non clauditur" (AKMKr: Vis. 24, s. $124-$ Wsola).

20 J. B y stroń, Dzieje obyczajów w dawnej Polsce, t. 2, Warszawa 1976, s. 75; Z. Kuchowicz, Obyczaje staropolskie $z$ XVII $i$ XVIII w., Łódź 1975, s. 182 n. ${ }_{21}$ J. K r a c i k, Duszpasterstwo parafialne..., s. 232.

${ }^{22}$,Kościoły całymi latami czekały na konsekracje, święcenia kapłanów odbywały się nieregularnie, a o bierzmowaniu w ogóle nie słychać" (H. W y c zaw ski, Wprowadzenie do studiów w archiwach kościelnych, Warszawa 1956, s. 72). 
czenia sakramentu bierzmowania $\mathrm{w}$ życiu religijnym wiernych. W liście pasterskim z r. 1736 nie poświęcił mu osobnego rozdziału. W diecezji krakowskiej przy szafarstwie sakramentu bierzmowania trzymano się przepisów synodu prowincjalnego z r. $1628{ }^{23}$. Szafarzami sakramentu bierzmowania byli biskupi. Sam bp Lipski w ciągu 13-letniego pasterzowania w Krakowie udzielił tego sakramentu 4426 osobom ${ }^{24}$. Jego biskup pomocniczy Michał Kunicki w latach 1738-1745 wybierzmował 54258 osób ${ }^{25}$. Eącznie tedy sakrament ten otrzymały 58684 osoby, podczas gdy cała diecezja liczyła 899734 katolików $^{26}$. Stanowiło to zaledwie ok. $6,5^{0} \%$ liczby wiernych.

Okazjami do udzielania bierzmowania były konsekracje kościołów, uroczystości zakonne, święcenia kapłańskie, a także wizytacje parafii. Sakramentu tego udzielano w kościołach, a czasem na przykościelnych cmentarzach ${ }^{27}$. Kandydaci do bierzmowania - według opinii ówczesnych prawników kościelnych - powinni być ochrzczeni, mieć zrozumienie przyjmowanego sakramentu, co zwykle miało miejsce około 7 . roku życia. Ostateczna decyzja zależała od biskupa ${ }^{28}$.

Przepisy synodalne z r. 1628 nakazywały proboszczom pouczać wiernych o istocie i skutkach bierzmowania, a także przestrzegać ich przed przyjmowaniem go niegodnie. Katecheza przed bierzmowaniem obejmowała: nauczanie podstawowych prawd wiary, zachętę do spowiedzi św. przed przyjęciem sakramentu lub przynajmniej najszybciej po jego przyjęciu. W katechezie napominano, by ten sakrament przyjmować z wielką pobożnością, szacunkiem, zachować post eucharystyczny oraz by uczestniczący w obrzędzie nie wychodzili ze świątyni przed zakończeniem obrzędu i błogosławieństwem biskupa. Przyjmujący sakrament mieli przynieść na obrzęd czyste, lniane chusty, potrzebne do wycierania olejów świętych. Przy każdym bierzmowanym miał być opiekun, zwany patronem; przy kobietach - niewiasty, przy mężczyznach — mężczyźni. Przepisy synodalne wymagały, by świadkowie bierzmowania byli wybierzmowani oraz zabraniały prosić na opiekunów własnych ro-

${ }_{23}$ Synodus provincialis Gnesnensis [...]. A. D. 1628: De confirmatione.

24 AKM: Acta Pontificia C. I. R. D. Joannis in Lipe Lipski [...] conscripta ab A. 1734 , sygn. I- 14 , s. $57-64$.

25 AKMKr: Liber ordinatorum, consecrationis ecclesiarum, apellarum, altarium, immobilium portalium, calicium et campanarum per $R$. D. Michaelem Kunicki [...] 1727 , s. $540-545$.

26 B. Kumor, Nieznane źródta do statystyki ludności diecezji krakowskiej w XVIII w., [w:] Przeszłość demograficzna Polski, t. 4, Lublin 1971, s. 33.

$27 \mathrm{~W}$ dniu 22 lipca $1738 \mathrm{r}$. bp Kunicki bierzmował 3465 osób w parafii Łączna. Trudno sobie wyobrazić, by się wszyscy pomieścili w kościele (AKMKr: Liber ordinatorum [...] Kunicki [...], s. 536).

${ }_{28}$ „Quod sint baptisati, et quod habeant usum rationis, qui solet praesumi circa septennium - sed in hoc exuberat episcopi" (Erotemata Ecclesiastica Joannis Clericati, praepositi Pataviensis, Venetiis 1743, s. 250). 
dziców, witrykusów, macochy, mężów lub żony. Synod postanawiał również, że mogą patronować $w$ tym obrzędzie najwyżej dwie lub trzy osoby. Postanowienia synodalne zobowiązywały rządców parafii do zapisywania w księgi bierzmowanych imion i nazwisk przyjmujących sakrament bierzmowania, przy czym załączały one wzór, jak należy to wykonać. Formularz wpisu obejmował rok, miesiąc i dzień bierzmowania, nazwisko biskupa, imię bierzmowanego i imię patrona ${ }^{29}$.

W oparciu o przeprowadzoną kwerendę trudno stwierdzić jak realizowano powyższe przepisy w diecezji krakowskiej za rządów bpa Lipskiego. Jak wspomniałem wcześniej, sakramentu bierzmowania, obok bpa Lipskiego, udzielał także jego biskup pomocniczy Michał Kunicki. O przygotowaniu wiernych do bierzmowania też niewiele możemy powiedzieć; notatka o dwóch bierzmowaniach z okazji misji parafialnych może być wskazówką, że $w$ tych parafiach wierni byli dobrze przygotowani do przyjęcia tego sakramentu zarówno pod względem wiedzy, jak i duchowo (wiadomo, że podczas misji uczono prawd wiary i przygotowywano do spowiedzi i komunii św.). W czasie misji bierzmowano w Bolechowicach i Pleszowie ${ }^{30}$, natomiast w większości parafii udzielano tego sakramentu przy okazji konsekracji kościoła lub wizytacji biskupiej, ale jak byli przygotowani wierni do przyjęcia tego sakramentu - nie wiemy. Jest faktem, że wizytatorzy nie pytali o bierzmowanie W parafii ani o księge bierzmowanych, co nasuwa podejrzenie, że ani bp Lipski, ani jego wizytatorzy, a w ślad za nimi również proboszczowie i wierni nie byli zainteresowani tym sakramentem ${ }^{31}$.

\section{MSZA SWIEtTA, NAJSWIĘTSZY SAKRAMENT, KOMUNIA SWIEtTA}

Wspólnotowy i publiczny charakter służby Bożej eucharystycznej, podkreślony przez Sobór Watykański II (Konstytucja o świętej liturgii, 41-42), był od początku w pełnej świadomości Kościoła. Polskie ustawodawstwo synodalne poświęcało Eucharystii, jej celebracji, uczestnictwu wiernych bardzo dużo uwagi. Już synod metropolity Jakuba Swinki w r. 1285 nakazywał dzwonić w czasie podniesienia ${ }^{32}$. Synod prymacjalny w Kaliszu w r. 1457 zabronił odprawiać więcej mszy św. ani-

29 Synodus prov. Gnesn. [...] A. D. 1628: De confirmatione.

30 AKMKr: Liber ordinatorum [...] Kunicki [...], s. 535.

${ }_{31}$ T. Długosz, Sprawy liturgiczne $w$ XVI wieku $w$ diecezji krakowskiej. Próbka z obszaru kilkunastu parafii, „Ruch Biblijny i Liturgiczny” 4 (1951) s. 305; M. L a skowski, jw., s. 97; W. Schenk, jw., s. 71; J. Kracik, jw., s. 233.

${ }_{32}$ Zbiór statutów synodalnych polskich powszechnych $w$ prowincji gnieznieńskiej, [w:] Starodawne Prawa Polskiego Pomniki, wyd. Z. H el c el, t. 1, Warszawa 1856 , s. 386. 
żeli jedną w ciągu dnia ${ }^{33}$. Wyjątek stanowił dzień Bożego Narodzenia, w którym od początku VII w. kapłani odprawiali trzy msze św. Synod prymasa J. Łaskiego polecał, by kapłani odczytywali teksty mszy św. głośno i zrozumiale dla ludu ${ }^{34}$. Gruntowną reformę obrzędów i tekstów mszalnych przeprowadził papież Pius V (1566-1572). Kościół w Polsce przyjął te reformy na synodzie prymacjalnym w Piotrkowie w r. 1577, a następnie biskupi $w$ poszczególnych diecezjach poczęli je wprowadzać $\mathrm{w}$ życie.

List pasterski kard. Maciejowskiego do proboszczów, zwany „Pastoralną", poświęcił dużo miejsca mszy św. Pastoralna zabraniała odprawiania mszy św. w prywatnych kaplicach bez pozwolenia ordynariusza. Dużo miejsca poświęcała kościołom, w których sprawowano Najśw. Ofiarę. Ołtarze miały być konsekrowane z portatylami, nakrywane trzema, czystymi obrusami. Szaty liturgiczne, bielizna kielichowa powinny być schludne i czyste. Kielichy i pateny należało pozłacać lub posrebrzać. Godnym szafarzem mszy św. mógł być tylko kapłan, i to wolny od kar kościelnych i grzechów ciężkich. W czasie celebracji powinien przestrzegać przepisów liturgicznych, a nuty i teksty do śpiewu brać z Graduału krakowskiego. W Pastoralnej znalazły się także przepisy odnoszące się do wiernych. Biskup zakazywał wychodzić z kościoła po podniesieniu; przypominał przepisy drugiego przykazania kościelnego, które nakazuje, by wierni byli na całej mszy św. Jest tam również wzmianka o obrzędzie przynoszenia ofiar do ołtarza i całowania krzyża, który to zwyczaj polecał biskup zachować według roztropności duszpasterzy ${ }^{35}$.

Następcy kard. Maciejowskiego przypominali te przepisy zarówno na synodach diecezjalnych, jak i w listach pasterskich. Na uwagę zasługuje bp Marcin Szyszkowski (1616-1630), który w Reformationes generales z r. 1620 wiele miejsca poświęcił mszy św. Żądał, by wszyscy rządcy parafii postarali się o nowe księgi liturgiczne, antyfonarze, psałterze i graduały drukowane $\mathrm{w}$ Krakowie, $\mathrm{z}$ tekstami i melodiami zgodnymi z mszałem rzymskim. Pragnąc ujednolicić odmawianie tekstów Gloria i Credo biskup wymagał, by celebransi trzymali się ściśle tekstu mszalnego i nie dodawali w Gloria - „Maria Sanctificans”, oraz w Credo - „Sancte Spiritus” po słowach „,Domine, Fili Unigenite, Jesu Christe". Wyznanie wiary polecił śpiewać całe, a nie jak to było praktykowane, że część tego tekstu śpiewano, a część recytowano. Przy śpiewie prefacji i Ojcze nasz zalecał używać melodii z mszału rzymskiego, ale

33 Materiaty do historii ustawodawstwa synodalnego $w$ Polsce $w$ w. XVI, wyd.

B. Ula nowski, [w:] Archiwum Komisji Prawniczej, t. 1, Kraków 1895, nr 18.

34 Tamże, s. 503 (nr 24).

35 Synodus provincialis 1628, s. 43-46. 
pozwalał, zwłaszcza starym kapłanom, śpiewać wedle dotychczasowej praktyki. Zakazał jednak śpiewu hymnu Veni Sancte Spiritus bezpośrednio po prefacji, gdyż w tym czasie miał być śpiewany hymn Swięty, Swięty, Swięty. Po podniesieniu zachęcał do ciszy i milczenia, gdyż jak pisał - taki sposób zachowania się najbardziej odpowiada wskazaniom mszału rzymskiego. Podobnie po komunii nie wolno było dodawać modlitw Nunc dimittis czy O sacrum convivium, których nie było w mszale rzymskim, a czas pokomunijny należało poświęcić pobożnej adoracji. Na zakończenie mszy św. celebrans powinien całe Ite missa est odśpiewać odwrócony twarzą do ludu; była bowiem praktyka, że część śpiewano twarzą do ludu, a część słów twarzą zwróconą do ołtarza. Przed błogosławieństwem należało dodać formułę: ,sit nomen Domini benedictum in saecula", a słowa właściwe błogosławieństwa winno się śpiewać głośno i wyraźnie. Bp Szyszkowski apelował do kapłanów, zwłaszcza do mniej wykształconych, by przygotowywali się do czytania tekstów, trosce kapłanów polecał także teksty śpiewane przez wiernych w języku ojczystym w okresie Wielkiego Postu, Wielkanocy i Zielonych Swiąt, by nie było w nich błędów niegodnych świętych tajemnic. Podtrzymywał dalej praktykę nakładania ofiar w czasie mszy św. i całowania krzyża przez wiernych, a tam, gdzie tego nie praktykowano, zalecal wprowadzić, pozostawiając jednak tę sprawę roztropności proboszczów ${ }^{36}$.

Bp Lipski w swojej działalności duszpasterskiej dotyczącej mszy św. nawiązywał do przepisów ogólnokościelnych i tradycji diecezjalnej. We wstępie cytowanego listu pasterskiego, mając na uwadze świętość ofiary mszy św., pisał: „Bóg zażąda czy Ciało i Krew Pańska nie było źle sprawowane" ${ }^{37}$. W rozdz. 11 wspomnianego listu przypominal rządcom kościołów i zakrystianom, aby nie dopuszczali do ołtarza kapłanów bez odpowiednich dokumentów; czynił tak dlatego, by zapobiec niegodnemu odprawianiu mszy św. ${ }^{38}$ Szacunek należny Najśw. Sakramentowi skłonił go do przypomnienia nakazu przestrzegania porządku rubryk i ceremonii przy jej sprawowaniu ${ }^{39}$. Mając na uwadze ważność mszy św. w duszpasterstwie, polecił kapłanom, a szczególnie duszpasterzom, by odprawiali msze św. za wiernych, a dziekanom nakazał sprawdzanie w czasie wizytacji, czy proboszczowie odprawiają msze św. w niedziele i święta i czy czynią to $\mathrm{w}$ czasie odpowiednim dla wiernych ${ }^{40}$. Do obowiązków dziekańskich należała również kontrola odprawiania mszy fundacyjnych. Zdarzało się, zwłaszcza w miastach, że wierni nie mogli zdą-

${ }^{36}$ RGSz: De Sancto Missae Sacrificio, s. 62-65.

${ }^{37}$ ELip: Wstęp.

${ }^{3}$ ELip: De vagis non admittendis ad Sacrificium Missae.

${ }^{39}$ ELip: De administratione sacramentorum.

${ }^{40}$ ELip: De residentia parochorum eorumque vicariis. 
żyć na mszę św. do kościoła parafialnego, ponieważ w zakonnych kościołach przedłużano kazania. Bp Lipski zwrócił uwagę na ten problem i polecił zakonnikom, by na tyle skrócili czas głoszenia kazań, aby wierni mogli zdążyć do kościoła parafialnego na mszę św. niedzielną lub świąteczną ${ }^{41}$. Z powyższego jednak wynika, że nie dostrzegał on potrzeby dokładniejszego pouczenia duchowieństwa i wiernych o mszy św. Był przekonany, że duszpasterze mają księgi liturgiczne, znają przepisy i obrzędy; uważał zapewne, że drukowana co roku Rubrycela wystarcza duszpasterzom $\mathrm{w}$ tym zakresie ${ }^{42}$.

Wizytatorzy, kierując się wskazówkami bpa Lipskiego, zwracali uwagę tylko na to, czy $w$ parafii odprawiana jest msza św. w niedzielę i święta oraz czy jest śpiewana. Nigdzie nie załączali porządku nabożeństw ani godzin ich celebracji. Wydaje się, że w parafiach wiejskich i miejskich praktykowany był porządek podany w wizytacjach z r. $1748^{48}$. Według tego porządku główną mszą św. w kościołach parafialnych była suma. Przygotowaniem do niej było śpiewanie jutrzni brewiarzowej, godzinek o N.M.P., odmawianie różańca, katechizacja i kazanie. Po ich zakończeniu odprawiano mszę św. W niektórych parafiach suma rozpoczynała się o godz. $10 \mathrm{i}$ trwała pełną godzinę.

W większości parafii dziesięciu dekanatów wizytowanych duszpasterze odprawiali msze św. niedzielne i świąteczne. Jedynie w Bodzentynie, Potoku Królewskim i Padwi wizytator upomniał proboszczów, aby odprawiali mszę św. w niedziele i święta ${ }^{44}$. W Ociesękach i Szumsku wizytatorzy zwrócili uwagę plebanom, by mszę św. śpiewali, a nie recytowali ${ }^{45}$. W pozostałych parafiach nie było żadnych uchybień pod tym względem. W siedmiu dekanatach duszpasterze pilnowali obowiązku odprawiania mszy św. i starali się godnie ją sprawować; podobnie było $\mathrm{w}$ innych dekanatach ${ }^{46}$. W wizytacjach nie mamy żadnych informacji o tym, jak wierni spełniali obowiązek uczestniczenia we mszy św. w niedziele i święta. Ze współczesnych pamiętników wynika, że wierni chętnie uczęszczali na msze św. i to nie tylko w niedziele, ale i w dni powszednie. Kitowicz tak pisał: „Nie tylko w dni święte, ale też w dni powszednie z trudem ktoś mający czas wolny opuszczał mszę św." ‘7 Z tym poglądem zgadza się J. Kracik: „Trwały i powszechny konfor-

41 ELip: De regularibus.

${ }_{42}$ Rubricella Dioecesis Crac. iuxía rubrices generales Breviarii et Missalis Romani S. Rit. Congregat., 1735, vol. 1; 1738, vol. 2; 1745, vol. 3.

${ }_{48}$ M. L a s k o w s k i, jw., s. 88; J. Kra c i k, jw., s. 235.

${ }_{44}$ AKMKr: Vis. 27, s. 20 (Bodzentyn); Vis. 27, s. 69 (Potok Królewski); Vis. 25, s. 354 (Padew).

45 AKMKr: Vis. 27, s. 64 (Ociesęki); Vis. 27, s. 95 (Szumsko).

${ }_{46}$ Por. wyżej przypis 43.

47 J. Kitowicz, Opis obyczajów za panowania Augusta III, opr. R. Pollak, Wrocław 1951, s. 21. 
mizm wioskowych i małomiasteczkowych społeczności sprzyjał praktyce coniedzielnej mszy św. Ale choć regułą było cotygodniowe uczestniczenie we mszy św., mimo skąpych danych źródłowych można stwierdzić, że na terenie dekanatu Nowa Góra nie wszyscy uczestniczyli w niej systematycznie" ${ }^{48}$. Jeszcze mniej wiemy, jak wierni w tej mszy św. uczestniczyli. Wydaje się, że z powodów językowych, tajemniczości obrzędów, ludzie patrzyli, słuchali i zachowywali się biernie, choć zapewne $\mathrm{z}$ wielką czcią i uszanowaniem odnosili się do świętych tajemnic.

Odnośnie do kultu Najśw. Sakramentu za czasów bpa Lipskiego w diecezji krakowskiej obowiązywały przepisy ogłoszone na synodzie prowincjalnym w Piotrkowie w r. $1551^{49}$. Według nich Najśw. Sakrament należało przechowywać $\mathrm{w}$ tabernakulum zamkniętym i otoczonym czcią. Korporały i obrusy miały być wyprane i czyste. Bp Lipski nie dodał nic więcej w tym zakresie. O czci należnej Najśw. Sakramentowi pisał: „My biedni śmiało i odważnie dotykamy świętości Sanctissimum, a jeśli rozważymy niewinność i niewidzialną moc Bożą, do obejścia świętego powinniśmy wchodzić skromnie ubrani z pochylonym czołem" ${ }^{50}$.

Wizytatorzy bardzo skrupulatnie kontrolowali i notowali jak duszpasterze przechowywali Najśw. Sakrament. Ich notatki przekonują, że proboszczowie bardzo dbali o tabernakulum. W większości wizytowanych dekanatów były one na wielkim ołtarzu, dobrze zamknięte, pięknie przyozdobione, naczynia i korporały czyste. Czystość była i w samych tabernakulach. W Sulisławicach paliła się przed tabernakulum lampka wieczna, a proboszcza z Borkowic wizytator pochwalił za wielką cześć dla Najśw. Sakramentu ${ }^{51}$. Zaniedbania były nieliczne; tylko w Cmińsku i Jedlnej tabernakulum było źle zamykane, a w Korytnicy, Brzozie, Zbylutce, Szumsku, a także we wspomnianych wyżej Ćmińsku i Jedlnej korporały były brudne i w tabernakulach znajdował się proch ${ }^{52}$.

Pozostaje jeszcze do omówienia zagadnienie komunii św. Bp Lipski pozostawił w tym zakresie niewiele wskazań. „Chorych trzeba pouczyć pisał on - o najważniejszych prawdach wiary koniecznych do zbawienia i zanim udzieli się im komunii przygotować ich aktami do godnego jej przyjęcia". Zaakceptował przepisy synodu prymacjalnego z r. 1628 $\mathrm{w}$ tej sprawie, obowiązujące $\mathrm{w}$ diecezji krakowskiej. One to, uzasadniając ważność komunii św. w życiu religijnym wiernych, pouczały, że ,,komunia św. jest chlebem życia, który z nieba zstąpił, danym nam,

48 J. Kr a c i k, jw., s. 235.

${ }^{49}$ CSM: De custodia Eucharistiae, s. 230.

50 ELip: Wstęp.

51 AKMKr: Vis. 25, s. 82 (Sulisławice); Vis. 24, s. 101 (Borkowice).

52 AKMKr: Vis. 24 s. 119 (Jedlna), s. 275 (Korytnica), s. 185 (Brzoza); Vis. 27 s. 87 (Szumsko), s. 37 (Ćmińsko). 
byśmy nie ustali w drodze do nieba". Przypominały czwarte przykazanie kościelne, by przynajmniej raz $\mathrm{w}$ roku $\mathrm{w}$ okresie wielkanocnym komunię św. przyjmować i wyznaczały czas jej przyjęcia między Niedzielą Palmową i Niedzielą Białą; komunię św. pozwalały udzielać w czasie wielkanocnym wszystkim, którzy się wyspowiadali i nie byli w karach kościelnych. Dzieci można było dopuścić do Stołu Pańskiego po pouczeniu i egzaminie. Proboszcz miał obowiązek w katechezie pomóc dzieciom zrozumieć tajemnice Eucharystii. Podobnie według przepisów synodalnych należało postępować $\mathrm{z}$ chorymi na umyśle; można im było udzielić komunii św., jeśli mieli jakąkolwiek świadomość lub wyrażali pragnienie przyjęcia jej, zwłaszcza w chorobie. Należało jednak uważać, by nie było znieważenia Najśw. Sakramentu. Wszystkich przyjmujących komunię św. obowiązywał post eucharystyczny od północy. Specjalne przepisy wydał synod dla kapłanów i wiernych przy zanoszeniu komunii św. chorym. Kapłanowi mieli towarzyszyć wierni ze świecami i śpiewem dla uczczenia Najśw. Sakramentu. W domach, gdzie byli chorzy, powinno się zadbać o czystość; na stole powinny się znajdować obrazy świętych, a w ich braku krzyż i woda święcona, obok nich zapalone świece. Synod zobowiązywał duszpasterzy zaopatrywać chorych w niebezpieczeństwie śmierci o każdej porze dnia i nocy. Ojcowie synodalni pamiętali również o więźniach. Zwracali się z apelem do władz świeckich, by przed wykonaniem wyroku śmierci ułatwiły skazańcom przyjęcie komunii św. w celi więziennej ${ }^{53}$.

Niewiele możemy powiedzieć - $\mathrm{z}$ braku odpowiednich przekazów źródłowych - jak w rzeczywistości wyglądała praktyka komunii św., przygotowanie do niej, ilość wiernych przyjmujących Pana Jezusa, i to nie tylko w czasie wielkanocnym, ale zwłaszcza poza nim. Podawane liczby wiernych spowiadanych $\mathrm{w}$ parafiach $\mathrm{w}$ czasie wielkanocnym mówią, że proboszczowie pilnowali praktyki komunii św. wielkanocnej, a wierni korzystali z niej prawie wszyscy. Prawdopodobnie i takie uroczystości jak odpust parafialny, uroczystości brackie, a zwłaszcza misje, były okazją do spowiedzi i komunii św., szczególnie, gdy wierni chcieli zyskać odpusty, z otrzymaniem których związana była praktyka komunii św. ${ }^{54}$ Podobnie bractwa dewocyjne polecały swoim członkom częste przystępowanie do komunii św. Nadużycia w praktyce udzielania tego sakramentu były bardzo nieliczne i zapewne odosobnione ${ }^{55}$.

53 Synodus provincialis 1628: De Sacrosancta Eucharistia. De processione cum S. Sacramento.

54 „Faktycznie wzrastała liczba komunikujących w XVII i XVIII wieku" (W. S ch enk, jw., s. 95). Por.: J. Kracik, jw., s. 238.

$55 \mathrm{Ks}$. Marcin Janaszewski, proboszcz we Wsole, udzielał komunii św. późnym wieczorem (Vis. 24, s. 129); ks. Stanisław Chojnacki, proboszcz maciejowicki, komunikował na plebanii, a puszkę z komunikantami przynosił z kościoła parafianin (Vis. 24, s. 269). 


\section{NABOŻEŃSTWA I PRAKTYKI POBOŻNE}

Bogactwo przeżyć religijnych przejawiało się również $\mathrm{w}$ wielości nabożeństw i praktyk religijnych. W pierwszej połowie XVIII stulecia wierni w diecezji krakowskiej w każdej parafii w niedziele i święta, a także w dni powszednie modlitwą chwalili Boga, dziękowali Mu i prosili o dary. Rano, w południe i wieczorem do modlitwy wzywał dzwon kościelny. W domach pańskich, jak pisał Kitowicz, „we wieczór zszedłszy się wszyscy do kaplicy odprawiali nabożeństwo pospolicie z litaniów różnych i pieśni tudzież modlitw złożone" ${ }^{56}$. Tej praktyce poświęcił bp Lipski jeden $\mathrm{z}$ rozdziałów listu pasterskiego, zatytułowany: $O$ modlitwie rannej $i$ wieczornej $i$ za zmartych. ,Nie tylko winno się prosić o błogosławieństwo i łaskawość Bożą przed wschodem słońca - pisał ale zawsze należy dziękować za dobra Opatrzności Bożej". Nakazywał więc, by w miastach dzwoniono trzy razy, zaś na wsi dwa razy dziennie. Na głos dzwonu o wschodzie i zachodzie słońca lub w jedną godzinę po zachodzie słońca zalecał odmawianie Anioł Pański i modlitw za zmarłych, nie wyznaczając szczegółowo tych ostatnich ${ }^{57}$. Wspomniany przez Lipskiego synod prymacjalny z r. 1621 zachęcal do odmawiania Ojcze nasz, Zdrowaś Maryo i psalmu De profundis ${ }^{58}$. W zakończeniu apelował do duszpasterzy, by nauczali wiernych tej modlitwy i zachęcali do jej odmawiania.

O wiele okazalej i uroczyściej świętowali wierni nabożeństwa w każdą niedzielę i święto. Od rana śpiewano w kościołach jutrznię brewiarzową, godzinki do NMP, różaniec lub inne pobożne pieśni ${ }^{59}$. W niektórych parafiach do wymienionych nabożeństw dodawano śpiewanie koronki do Trójcy św. i o Męce Pańskiej oraz pieśni o Matce Bożej ${ }^{60}$. Po mszy św. śpiewano Anioł Pański. Po południu zbierali się wierni w kościele na nieszporach. Szczególną oprawę, nie zawsze służącą pobożności, miały zwyczaje urządzania „Jasełek”, „Żłóbka” oraz odwiedzanie Grobów Pańskich w Wielki Piątek i Wielką Sobotę. Szczególnie w Wielkim Poście, a zwłaszcza w Wielkim Tygodniu, kościoły obfitowały w nabożeństwa. Kitowicz wspomina, że w Wielkim Poście w kościołach parafialnych po nieszporach śpiewali wierni po polsku pieśni o Męce Pań-

58 J. Kitowicz, jw., s. 21.

57 ELip: De oratione matutina, vespertina et pro defunctis.

58 Synodus provincialis Gnesn. 1621: De oratione pro mortuis.

59 J. Kracik, jw., s. 235; M. L a s k ow ski, jw., s. 77.

60 ,Chcąc jak najbardziej chwałę i cześć Boską promować w każdą niedzielę i święto po nabożeństwie śpiewali dwie pieśni do Matki Bożej: Bądź pozdrowiona Panienko Maryjo, Do Ciebie Matko my grzeszni wołamy - zapis Stanisława Wyżyckiego z r. 1732 (J. Wiśniewski, Dekanat opatowski, Radom 1907, s. 165). Ks. Kazimierz Dziewulski, proboszcz w Ćmielowie, praktykował śpiewanie w każdą niedzielę rano koronki o Trójcy św., a po południu koronki o Męce Pańskiej (tamże, s. 55). 
skiej, a w miastach praktykowano nabożeństwa zwane „Pasją”. Uczestniczyli w nich członkowie bractw kościelnych oraz kapnicy, „którzy oprócz modlitwy biczowali się i w przepisanym porządku całowali krzyż" ${ }^{61}$.

Wypada jeszcze wspomnieć o nowych nabożeństwach, które za czasów bpa Lipskiego wprowadzano w kościołach zakonnych. W Krakowie reformaci początkowo tylko w piątek odprawiali po komplecie Drogę Krzyżową, później we wszystkie niedziele i święta w godzinach popoludniowych przed nieszporami lub po nich. Z praktykami tymi łączyło się budowanie Drogi Krzyżowej na zewnątrz kościołów ${ }^{62}$. Szczególnie uroczyście obchodzono odpusty, zwłaszcza w kościołach zakonnych. Towarzyszyły im procesje i wystawienie Najśw. Sakramentu. W Krakowie do największych procesji należała tradycyjna, rok rocznie urządzana procesja z Wawelu na Skałkę dla uczczenia św. Stanisława Biskupa i Meczennika ${ }^{63}$. Uczestniczyły $\mathrm{w}$ niej wszystkie krakowskie parafie i kościoły zakonne. Podobna jej, choć mniej uroczysta, była procesja do grobu św. Jacka w kościele oo. Dominikanów (w sierpniu). Od r. 1735 w dzień Wniebowzięcia Najśw. Maryi Panny (15 sierpnia) wyruszała z Wawelu do kościoła mariackiego procesja zapoczątkowana przez archiprezbitera tegoż kościoła ks. Jacka Łopackiego ${ }^{64}$. Wypada też wspomnieć o jednej nadzwyczajnej procesji, którą wraz z dworem królewskim z Wawelu na Skałkę odprawił August III Sas (1733-1763), król polski, z okazji swojej koronacji w r. $1733^{65}$.

Oprócz tych uroczystych procesji, w każdym kościele parafialnym i zakonnym praktykowano procesje $\mathrm{z}$ okazji świąt kościelnych przepisanych przez rytuał piotrkowski. W Niedzielę Palmową, w uroczystość Zmartwychwstania Pańskiego i w Boże Ciało wychodzono z procesjami poza świątynię, by publicznie oddać Bogu cześć. Szczególnie w Boże Ciało procesja miała wspaniałą oprawę; brali w niej udział wszyscy wierni, organizacje brackie, cechowe i wojsko. Uczestnicy śpiewami, modlitwami, a także wystrzałami z różnych rodzajów broni palnej oddawali cześć publiczną Najśw. Sakramentowi ${ }^{66}$. Natomiast mniej uroczyste były procesje w święto Matki Bożej Gromnicznej, w Dni Krzyżowe i w dzień

61 J. Ki tow ic z, jw., s. 41, 48, 51, 59.

62 J. Pasiecznik, Dziatalność klasztoru Franciszkanów Reformatów w Krakowie 1625-1978, Kraków 1980, s. 10-35.

${ }_{63}$ M. Jagosz, Przedrozbiorowe procesje wawelskie ku czci świętego Stanisława biskupa i męczennika, Kraków 1975, s. 24 (maszynopis - PAT Kraków).

${ }_{64} \mathrm{~J} . \mathrm{K}$ u ś, Dziatalność kulturalno-oświatowa ks. Jacka Łopackiego 1690-1761, „Nasza Przeszłość” 40 (1973) s. 207; tenże, Jacek Łopacki $i$ nowe o nim przyczynki, "Rocznik Krakowski” 50 (1980) s. 118.

${ }_{65}$ M. R o ż e k, Ostatnia koronacja w Krakowie, „Rocznik Krakowski” 44 (1973) s. $97-112$.

${ }_{66}$ J. Ki tow i c z, jw., s. 53-58. 
św. Marka. Miały one charakter raczej prośby o opiekę Matki Bożej i błogosławieństwo Boże w różnych potrzebach. W dni odpustowe, w uroczystość Zmartwychwstania Pańskiego, w czasie 40-godzinnego nabożeństwa i w Boże Ciało odprawiano nabożeństwa z wystawieniem Najśw. Sakramentu.

Bp Lipski wiedział o praktykowanych nabożeństwach w swojej diecezji, ale w nauczaniu pasterskim zwrócił jedynie uwagę na wystawianie Najśw. Sakramentu i procesje. Pisał na ten temat: „Zakazujemy pod sądem czynić częste wystawienia Najśw. Sakramentu, bo to umniejsza cześć dla Chrystusa wśród ludzi". Przepis ten obowiązywał duszpasterzy diecezjalnych i zakonnych. W kościołach zakonnych wolno było wystawiać Najśw. Sakrament tylko w święta określone przywilejem, natomiast $\mathrm{w}$ innym czasie trzeba było uzyskać pozwolenie władzy duchownej ${ }^{67}$. Podobne przepisy odnosiły się do procesji publicznych i wystawienia Najśw. Sakramentu w parafiach: można je było urządzać w dnie uprzywilejowane, a w inne - za pozwoleniem władzy biskupiej. Przepis ten odnosił się tylko do kościołów zakonnych.

Dotychczas omówione nabożeństwa były praktykowane każdego roku. Gdy zachodziły jednak nadzwyczajne wydarzenia lub okoliczności (np. klęski żywiołowe), odprawiano specjalne nabożeństwa. Uczynił to bp Lipski w r. 1739. W dniu 18 czerwca tegoż roku, w Kielcach, wydał specjalny list, w którym nakazywał, by we wszystkich kościołach katedralnych, kolegiackich, parafialnych i zakonnych w całej diecezji krakowskiej odprawiano nabożeństwo zwane suplikacjami. Duszpasterze mieli je odprawiać publicznie i uroczyście w poszczególne dnie, niedziele i święta. Po skończonym kazaniu lub po pierwszej mszy św., przy śpiewie $O$ salutaris Hostia należało zrobić wystawienie Najśw. Sakramentu w puszce i odśpiewać w języku polskim litanię do Wszystkich Swiętych z modlitwami o odwrócenie zagłady i wyproszenie zwycięstwa religii chrześcijańskiej. Po modlitwach należało śpiewać suplikacje. Przy końcu listu przekonywał duszpasterzy o potrzebie takiego nabożeństwa i zalecał, aby zachęcali wiernych do udziału ${ }^{68}$.

Obraz życia religijnego w diecezji krakowskiej za rządów bpa Lipskiego był bardzo urozmaicony i przebogaty. Biskup był przekonany o wielkiej wartości nabożeństw w życiu religijnym wiernych. Swiadczy o tym fakt wprowadzenia suplikacji oraz zalecenie w liście pasterskim, aby mieszkańcy szpitali, domów dla biednych, pobożnie odmawiali różaniec i koronkę do Matki Bożej. Księża odprawiali te nabożeństwa, choć

${ }^{67}$ ELip: De regularibus.

68 Joannes Alexander miseratione diuina S. R. E. presbiter card. Lipski episcopus Cracoviensis [...] datum Kielciis in palatio nostro episcopali die desima octava mensis Junii A. D. 1739. 
zdarzały się zaniedbania. Nie wszyscy $\mathrm{z}$ nich starali się o pozwolenie na wystawienie Najśw. Sakramentu, mimo że dokonywali tego aktu liturgicznego. Wprawdzie nie każdy wizytator sprawdzal te pozwolenia u proboszczów, ale nawet z zachowanych notatek wynika, że wielu proboszczów takich pozwoleń nie miało. Np. w dekanacie kunowskim na sześć wizytowanych parafii aż trzy nie miały pozwolenia na wystawianie Najśw. Sakramentu (Mychów, Szewna, Krzyżanowice) ${ }^{69}$. W parafiach Zwoleń i Pawłowice zaniedbywano odmawiania różańca ${ }^{70}$, w Kleczanowie, Krzyżanowicach proboszczowie nie odprawiali nieszporów ${ }^{71}$, a w Lelowie i Żurawiu wizytator nakazał dzwonić na Anioł Pański ${ }^{72}$.

Z nabożeństwami łączyły się również praktyki pobożne, których celem było duchowe dobro ludzi wierzących. Najbardziej popularną z nich był post. Wstrzymywano się od jedzenia mięsa w piątki całego roku oraz przez cały Wielki Post ${ }^{73}$; poszczono nadto $\mathrm{w}$ soboty, wtorki i środy, ale były to już praktyki prywatne i dobrowolne. Wierni należący do bractw szkaplerza św. lub mający specjalne nabożeństwo do świętych Pańskich, przez post $w$ soboty lub przez dziewięć, siedem czy pięć wtorków poprzedzających uroczystość Swiętych, chcieli uzyskać specjalne odpusty lub też uprosić łaski Boże i podziękować Bogu za opiekę ${ }^{74}$.

Bp Lipski, nawiązując do listu bpa Maciejowskiego i zwyczajów obowiązujących w diecezji, przypomniał wiernym w swoim liście pasterskim przepisy postne. Tłumaczył sens postu: „Przez ćwiczenie ciała — pisał w doskonałym stopniu duch wznosi się do Boga, powiększa się cnota, pomnaża się zasługa, ożywia wiara, pobożność się doskonali”. Następnie przypomniał obowiązujące przepisy postne, zwracając uwagę na wiek, w którym obowiązywał post ścisły. Wiernym, którzy ukończyli dwudziesty rok życia, a nie osiągnęli sześćdziesiątego, wolno było jeść raz dziennie do syta, zaś wieczorem lekki posiłek dla pokrzepienia sił. Następnie nakazywał duszpasterzom ogłaszać i przypominać w niedzielę $\mathrm{z}$ ambony terminy postów; wymienił w liście następujące dni postne: wigilie, suche dni, Wielki Post oraz dni, w których ludzie pościli w danej parafii wedle zwyczaju miejscowego. By zachęcić do praktykowania postów, zalecał duszpasterzom, aby pouczali wiernych o przepisach postnych oraz przekonywali o ważności i owocności postów ${ }^{75}$.

Jednakże tego samego roku, dnia 20 lutego 1737, bp Lipski udzielił dyspensy od postu w okresie Wielkiego Postu, a to ze względu na bar-

69 AKMKr: Vis. 27, s. 178 (Mychów), 184 (Szewna), 193 (Krzyżanowice). Podobna sytuacja była w dekanacie nowogórskim - por. J. K r a c i k, jw., s. 240.

70 AKMKr: Vis. 24, s. 165 (Zwoleń), 258 (Pawłowice).

71 AKMKr: Vis. 27, s. 193 (Kleczanów), 193 (Krzyżanowice).

72 AKMKr: Vis. 26, s. 220 (Lelów), 154 (Zuraw).

73 CSM: De observatione jejuniorum, s. 232; J. Kracik, jw., s. 242.

74 J. Kit o w i c z, jw., s. $37-38$.

75 ELip: De observatione ieiuniorum. 
dzo trudną sytuację społeczną. Pisał na ten temat: „Zagęszczone chorymi nie tylko szpitale, ale i pospolite domy, tudzież ludzie często i gęsto częścią z niedostatku, częścią z gwałtownych i zaraźliwych chorób po miastach, wsiach i miejscach umierają". By ulżyć i pomóc w tej biedzie, zwłaszcza ludziom ubogim i ciężko pracującym, powodowany prośbą duchownych i świeckich oraz lekarzy pozwalał, by we wspomnianym roku ,wszystkim wolno było używać wszelkich pokarmów tak z mięsa jako i nabiału oprócz śród, piątków i sobót aż do niedzieli kwietnej raz jeden na dzień, drugi za pomierną refekcją obchodząc się”. Przypominał jednak korzystającym z dyspensy, że mieli obowiązek nagradzać Bogu szczerą poprawą życia, modlitwą, uczęszczaniem do sakramentów świętych i innymi chrześcijańskimi cnotami. Możniejszym nakazał, ,by jałmużnami uboższych a osobliwie panowie swoich poddanych ratowali" ${ }^{76}$.

Praktykom postnym poświęcił bp Lipski jeszcze przedostatni swój list napisany w Krakowie dnia 22 stycznia 1742 r. (editum super servando ieiunio S. Quadragesimae). Bezpośrednią przyczyną wydania tego listu była nauka papieża Benedykta XIV (1740-1758) o wartościach duchowych postu. W breve z dnia 30 maja i 22 sierpnia 1741 r. papież przestrzegał biskupów przed łatwym i częstym udzielaniem dyspens od postów. Przypominał biskupom, by, zanim zwolnią wiernych od postu, brali pod uwage jedynie ważne i słuszne przyczyny oraz dorady lekarzy. Bp Lipski w liście pasterskim powyższe papieskie przepisy podał do wiadomości duchownym i wiernym swojej diecezji.

Biorąc pod uwage pouczenia duszpasterskie dotyczące praktyki postnej można stwierdzić, że bp Lipski doceniał w działalności duszpasterskiej wartość praktyk postnych i chciał, by były zachowywane, a przez zachęty przyczyniał się do ich ożywiania. Nie wiadomo natomiast, jak duchowieństwo i wierni stosowali się do tych wskazań, bo wizytatorzy nie zwracali uwagi na praktyki postne. Z pamiętników Kitowicza wynika, że wierni pościli nie tylko w dni nakazane, ale praktykowali inne dobrowolne posty ${ }^{77}$.

\section{POKUTA}

„Im częściej wierni popadają w bagnisko grzechów, tym częściej winno się ich zachęcać do sakramentu pokuty, który jest jedynym ratunkiem po grzesznym upadku, a proboszczowie winni ich przynaglać przynajmniej raz do roku do tego sakramentu w okresie Wielkanocy" -

${ }^{76}$ Processus dyspensy generalnej na kwadragesimę roku 1737, Kraków 20 luty.

77 Por. J. Kracik, jw., s. 242. 
głosił synod krakowski z r. $1711^{78}$. Również bp Lipski uznał szafarstwo tego sakramentu za najważniejszy obowiązek duszpasterski, spoczywający na kapłanach. W piątym rozdziale swego listu pasterskiego pisał: „Spowiednik jest okiem dla ślepych i podporą dla kulawych. Kapłan spowiadając, spełnia z upoważnienia Kościoła trzy zadania: sądzi, leczy i uczy”. Dlatego napominał: „Niech się nie odważa kapłan przystępować do sprawowania tego poważnego obowiązku, jeśli nie ma pisemnej jurysdykcji biskupiej". Udzielenie pozwolenia do spowiadania wiernych w diecezji krakowskiej uzależnił od świadectwa egzaminatorów prosynodalnych, wyznaczonych przez Konsystorz biskupi w Krakowie. Proboszczów i przełożonych zakonnych zobowiązywał w sumieniu, by do słuchania spowiedzi w swoich parafiach dopuszczali tylko kapłanów mających jurysdykcję. Nakaz ten powtarzał dwukrotnie. Postanawiał dalej, że gdyby spowiadający się dowiedział, że jego spowiednik nie miał pozwolenia go rozgrzeszyć, winien wówczas spowiedź powtórzyć. Podobnie rozstrzygał wątpliwość spowiedników, czy mogą spowiadać po wygaśnięciu jurysdykcji; zezwolił im spowiadać, lecz tylko w ostatecznej konieczności i w przypadku zagrażającej śmierci. Kapłanom, którzy samowolnie, bez odpowiedniej jurysdykcji spowiadali, groził karą suspensy ipso facto. W dalszym ciągu swego pouczenia zwracał uwagę na potrzebę posiadania przez kapłanów odpowiednich wiadomości do rozsądzania sumień ludzkich. Powinni więc umieć rozróżnić grzech ciężki od lekkiego, znać okoliczności obciążające lub zmniejszające ciężkość grzechu, dalej - powinni wiedzieć, jakie grzechy są zarezerwowane i komu. A wszystko to potrzebne jest spowiednikowi, aby wiedział, kiedy należy dać rozgrzeszenie i z jakich grzechów, a w jakich przypadkach odmówić go lub odłożyć. Dla dokształcenia księży w tym zakresie nakazywał czytanie dzieł najwybitniejszych moralistów, a na kongregacjach dekanalnych przypominanie przepisów odnoszących się do spowiedzi, a szczególnie dotyczących rezerwacji papieskich i biskupich. Zasadniczym motywem jego pouczeń i wymagań było godne spełnianie świętego urzędu spowiednika ${ }^{79}$. W przypadkach rozgrzeszania penitenta pozostającego $\mathrm{W}$ karach kościelnych polecał, by spowiednik przed absolucją przyjął przysięgę od spowiadającego się, że zachowa kościelne przepisy, nakazy władzy duchownej i dopełni restytucji. W przypadku choroby penitenta, utrudniającej naprawienie krzywdy, spowiadający się powinien pieniądze lub inne dobra materialne przeznaczone na restytucje zostawić w kościele albo u ludzi zaufanych; gdyby chory spowiadający się nie miał pieniędzy dla naprawienia krzywdy, powinien wskazać poręczyciela, a w przypadku niemożności dokonania tego, rozgrzeszenie mógł uzyskać po

78 SE: De paenitentia sacramento, S. 32.

79 ELip: De sacramento paenitentiae. 
złożeniu przysięgi, że po wyzdrowieniu w ciągu miesiąca naprawi krzywdę zgodnie z poleceniem władzy kościelnej. Spowiednik udzielający rozgrzeszenia wbrew powyższym przepisom przyjmował na siebie obowiązek naprawienia krzywd i zgłoszenia o tym władzy duchownej.

W pouczeniu o sakramencie pokuty zawarł bp Lipski przypomnienie przepisów prawnych, ale pominął wskazania praktyczne i duszpasterskie. Nic nie wspomniał o czasie spowiadania, nie pouczył kapłanów o przymiotach moralnych koniecznych przy szafarstwie sakramentu pokuty, nie wspomniał też o darmowości tego sakramentu.

W diecezji krakowskiej za rządów bpa Lipskiego praktyka pokutna odbywała się zgodnie $\mathrm{z}$ zaleceniami synodów prowincjalnych oraz synodu diecezjalnego z r. $1711^{80}$. Z wizytacji dowiadujemy się, że na 150 parafii w 10 wizytowanych dekanatach tylko w dwóch przypadkach duszpasterze nie mieli jurysdykcji do spowiadania. I tak w Wierzbicy ani proboszcz, ani wikariusz nie mieli jurysdykcji, a w Ćmińsku tylko prebendarz $^{\text {s1. }}$. Księża przywiązywali duże znaczenie do spowiadania parafian w okresie Wielkanocy; jedynie w dwóch parafiach na dziesięc dekanatów wizytator zaznaczył, że wielu ludzi nie było wyspowiadanych w czasie wielkanocnym; były to parafie Maciejowice i Korytnica ${ }^{82}$. Rzadko siadał w konfesjonale proboszcz w Zbylutce i wikariusz w Rakowie ${ }^{83}$. Spowiadano w konfesjonałach ustawionych w kościele; jedynym wyjątkiem był ks. Stanisław Chojnacki, proboszcz maciejowicki, spowiadający na plebanii, zaś proboszcz kłobucki słuchał spowiedzi w zakrystii ${ }^{84}$. Obaj tłumaczyli się, że czynią to z powodu choroby. Kard. Maciejowski zalecał praktykę dwukrotnej spowiedzi wielkanocnej ${ }^{85}$, o czym nie wspomina bp Lipski. Z przekazów źródłowych dowiadujemy się, że wierni spowiadali się $\mathrm{w}$ dni odpustowe oraz w czasie 40-godzinnego nabożeństwa. W parafii Zalas z okazji 40-godzinnego nabożeństwa w roku 1738 czterdziestu księży świeckich i zakonnych wyspowiadało w ciągu trzech dni 2300 osób z samego Zalasa i okolicy ${ }^{86}$. Wizytatorzy, znając tradycje i dawne przepisy diecezjalne, notowali swoje uwagi dotyczące praktyki spowiedniczej. I tak upominali proboszczów: ks. Jacka Ciemieleckiego w Korytnicy, by za spowiedź nie brał od parafian zapłaty, a ks.

so SE: De paenitentia sacramento, s. 32; J. Kracik, jw., s. 237; M. L a skowski, jw., s. 101.

${ }^{81}$ AKMKr: Vis. 24, s. 57 (Wierzbica - ks. Placyd Giebułtowski i ks. Filip Charąbniewicz, obaj cystersi); Vis. 27, s. 42 (Cmińsk - ks. Jan Salwin).

${ }^{52}$ AKMKr: Vis. 24, s. 269 (Maciejowice), 279 (Korytnica).

s3 AKMKr: Vis. 27, s. 99 (Zbylutka - ks. Stanisław Staszowski); „In excipiendi confessionibus diligentes exhibet" (Vis. 27, s. 84, ks. Jan Chrzanowski w Rakowie).

84 „Exauditis confessionibus tempore Paschali in suo hypocausto" (AKMKr: Vis. 24 , s. 269 - ks. Chojnacki); "Confessionem in zakristia non excipiant" (Vis. 26, s. 140 - Kłobuck).

85 Synodus provincialis 1628: De paenitentia, s. 38; W. Schenk, jw., s. 29.

86 J. Kra cik, jw., s. 238. 
Mariana Janoszewskiego we Wsole, by nie zmuszał do pracy wzamian za spowiedź ${ }^{8 \pi}$, ks. Wojciechowi Preysowi, proboszczowi w Kawali Stępocinie, zabronił wizytator zmuszania parafian z Guzowa, by się u niego spowiadali ${ }^{88}$. Delikatność przy spowiedzi zalecał wizytator ks. Jakubowi Konieckorowskiemu, proboszczowi w Żurawiu, bowiem parafianie skarżyli się na niego, że jest twardy i ostry ${ }^{89}$. Tego rodzaju upomnień było bardzo mało, z czego można wnioskować, że kapłani sumiennie i z poczuciem taktu wykonywali obowiązki spowiedników - przynajmniej w wizytowanych parafiach. Również $z$ wizytacji dowiadujemy się, że wszyscy wierni objęci obowiązkiem wielkanocnej spowiedzi przystępowali do niej; wyjątki były bardzo rzadkie, a zdarzały się wśród szlachty ${ }^{80}$.

Wypada jeszcze wspomnieć o przepisach bulli In Coena Domini, w której wyliczono grzechy zarezerwowane papieżowi. Zgodnie z zarządzeniem bpa Lipskiego bullę tę powinien mieć każdy proboszcz i czytać ją wiernym. Wizytator ks. Wacław Hieronim Sierakowski kontrolował fakt posiadania tej bulli. W dekanatach bodzentyńskim i kunowskim aż 12 proboszczów na 28 nie miało tekstu bulli i jej nie czytało ${ }^{91}$. Wprawdzie powyższe stwierdzenie dotyczy tylko dwóch dekanatów, ale można sądzić, że podobna sytuacja istniała w większości wiejskich parafii. Wydrukowanie tejże bulli przez bpa Lipskiego i udostępnienie jej duszpasterzom podyktowane było słuszną i uzasadnioną potrzebą.

\section{DUSZPASTERSTWO CHORYCH}

„Sakrament namaszczenia chorych ustanowiony przez Chrystusa Pana jako lekarstwo niebieskie nie tylko dla duszy, lecz również jako pożytek dla ciała, winien być udzielany ciężko chorym $\mathrm{z}$ wielką gorliwością i pilnością" - zalecał rytuał piotrkowski ${ }^{92}$. Nazwa sakramentu zgodna była z nauką teologii systematycznej XII i XIII w., która ze względu na skutki namaszczenia zwracała uwagę na ostatnie przed śmiercią odpuszczenie grzechów człowiekowi ${ }^{93}$. Biskupi krakowscy, opierając się na

87 „Praetendendo a parochianis solutionem” (AKMKr: Vis. 24, s. $279-$ ks. Jacek Ciemielecki); "Confessione confluentes nullo labore servili gravabat" (Vis. 24, s. 129 - ks. Marian Janaszewski).

88 AKMKr: Vis. 24, s. 49.

89 "Non sit asper et nimius durus sed affabilem se omnibus exhibant" (AKMKr: Vis. 26 , s. 154).

${ }_{90}$,Scandalosi sunt Magnifici Zabielski heredis et publici concubinarii” (AKMKr: Vis. 26, s. 113 - Przystań); Vis. 27, s. 323 (Stanisław Gemborzycki - Bobrowniki). 91 AKMKr: Vis. 27 (dek. Bodzentyn) - proboszczowie parafii Tarczek, Ćmińsk, Bieliny, Leszczyny, Ociesęki, Potok Chmielnicki nie mieli bulli; Vis. 27 (dek. K unów) Mychów, Mirzec, Krzyżanowice nie posiadały bulli.

${ }_{92}$ Rituale sacramentorum Cracoviae 1743, s. 47-63.

93 W. S c h e n k, jw., s. 64 . 
naukach Soboru Trydenckiego, w swoim pasterskim nauczaniu wiele uwagi poświęcali sakramentowi namaszczenia chorych; zwłaszcza kard. Bernard Maciejowski w liście pasterskim oraz bp Marcin Szyszkowski w Reformationes podali szczegółowe przepisy tyczące się tego sakramentu. Bp Lipski odwoływał się do ich pouczeń i wskazówek w tym zakresie. Kard. B. Maciejowski, mając na względzie przeżycia chorych oraz ich ogólne wyczerpanie zarówno fizyczne, jak i psychiczne, napominał proboszczów, aby z wielką gorliwością udzielali tego sakramentu po spowiedzi i komunii św. Nawet w wypadku utraty przytomności chorego, jeśli duszpasterz wiedział, że chory prosił o ten sakrament, winien namaścić go olejem świętym; gdyby nastąpił zgon chorego, obrzęd należało przerwać lub dokończyć go warunkowo. Przy akcie namaszczenia powinno się chorych podnosić na duchu, pomagać im wzbudzać akty nadziei chrześcijańskiej, a jeśli chory konał, duszpasterz powinien odmawiać z obecnymi modlitwy za umierających. W jednej i tej samej chorobie pouczył kardynał - można tylko raz udzielić tego sakramentu ${ }^{94}$. W rozdziale $O$ ostatnim namaszczeniu bp Lipski przypominał przepisy i nauke swoich poprzedników - kard. B. Maciejowskiego i bpa M. Szyszkowskiego. Uważał, że trzeba pisać i przypominać proboszczom o tym sakramencie, gdyż wiedział na podstawie wizytacji, że sakrament chorych był najrzadziej przyjmowany przez chorych. Jedynej i zasadniczej przyczyny tego zaniedbania biskup upatrywał w braku pouczeń duszpasterzy o znaczeniu tego sakramentu i sposobie jego przyjmowania; nieznajomością rzeczy tłumaczył więc brak należytego pragnienia przyjęcia przez chorych tego sakramentu. Nakazał przeto, by corocznie w niedzielę Trójcy św. i w pierwszą niedzielę adwentu proboszczowie jak najpilniej wyjaśniali wiernym naukę o sakramencie namaszczenia w oparciu o katechizm trydencki. Obarczył proboszczów obowiązkiem wykorzenienia fałszywego przekonania wiernych, że przyjęcie sakramentu chorych najczęściej było ostatnim aktem w życiu człowieka.

W dalszym ciągu swego pouczenia bp Lipski podawał przepisy odnoszące się do materii sakramentu. Olej chorych należało przechowywać oddzielnie w naczyniu cynowym lub srebrnym w ozdobnej puszcze, dobrze przytwierdzonej i zamkniętej w wielkim ołtarzu po stronie lekcji. Zakazywał przechowywania olejów św. w tabernakulum lub w zakrystii. Po oleje św. W Wielki Czwartek nakazał przysyłać do katedry duchownych, którzy mieli je zabrać dla poszczególnych parafii czy dekanatów. Przy omawianiu formy i sposobu udzielania sakramentu namaszczenia wskazał przepisy Agendy i szczegółowo je przytoczył. Podkreślił znaczenie namaszczenia $w$ nagłych przypadkach i przypomniał sło-

${ }_{94}$ EMac, s. 200; RGSz: De extrema unctione, s. 95-98. 
wa, które powinni w tej sytuacji wymawiać kapłani udzielający sakramentu namaszczenia. W dalszym ciągu swego pouczenia bp Lipski wymienił - za radą medyków - 21 objawów chorób przewlekłych i 6 objawów wypadkowych dla ułatwienia kapłanom rozpoznania stanu chorego i zadecydowania o potrzebie udzielenia mu namaszczenia; jeśli objawy wskazywały zbliżającą się śmierć, zobowiązywał duszpasterzy, by umiejętnie zachęcali chorego do przyjęcia sakramentu namaszczenia, a proszącym o niego bezzwłocznie go udzielali. Polecał otaczać chorych opieką i modlić się za nich; w tym celu kapłani powinni odwiedzać chorych, a wiernych zachęcać do niesienia im pomocy. Przestrzegał przed nadużyciami, zakazywał wymuszać na chorych zapisów na korzyść kościoła czy wyboru miejsca pogrzebu ${ }^{95}$.

Spróbujmy prześledzić na podstawie wizytacji wybranych dekanatów, jak praktycznie odnosili się duszpasterze do wskazań biskupich. W większości wizytowanych parafii oleje św. chorych były przechowywane w osobnych naczyńkach cynowych, które umieszczano w puszce zgodnie z przepisami. W trzech parafiach (Wierzbica, Włodowice i Krzyżanowice) puszki były ozdobne i wewnątrz, i na zewnątrz ${ }^{98}$. Jedynie w Cmińsku, Gródku i Zagnańsku naczyńka były stare, zniszczone i przeżarte rdzą ${ }^{97}$. Proboszczowie przechowywali $\mathrm{w}$ zasadzie puszki przy wielkim ołtarzu, ale w 10 parafiach przechowywali je w zakrystii, a w Baczkowicach - w chrzcielnicy ${ }^{98}$. Pomieszczenie na oleje św. było z reguły zamykane, lecz w 10 parafiach wizytator zwrócił proboszczom uwagę na ich złe przechowywanie. Tylko w jednej parafii, w Łagowie, nie było olejów św., a proboszcz tłumaczył się, że pożyczył je do kaplicy w Piórkowie ${ }^{99}$. Niekiedy wizytatorzy notowali, że na Wielkanoc oleje św. były odnawiane, ale tego rodzaju zapiski były rzadkie - widocznie wszystko było zgodne z przepisami. Prawdopodobnie duszpasterze, którzy katechizowali, mówili kazania w każdą niedzielę i święta, pouczając wiernych o sakramencie namaszczenia chorych $\mathrm{w}$ czasie nakazanym przez biskupa. Po zapoznaniu się z metrykami zgonów w parafii Tenczynek, Łazany i św. Jakuba w Krakowie można wyciągnąc wnioski, że duszpasterze chętnie śpieszyli do chorych i zależało im na tym, by wierni nie

95 ELip: De extrema unctione.

96 ,Eleganter extra et intra adornata” (AKMKr: Vis. 26, s. 36 - Włodowice); „Decentia armoliorum pro servandis sacris oleis” (Vis. 24, s. 57 - Wierzbica); „Decenter, bene clauso" (Vis. 27, s. 190 - Krzyżanowice).

${ }^{97}$,,Ineptum s. oleum in illo erugine asitum, et putridum non in armoriola" (AKMKr: Vis. 27 s. 37 - Cmińsk); Vis. 24 s. 227 (Gródek); Vis. 27 s. 31 - Zagnańsk).

93 Kazanów, Sucha, Swierze, Poczesna, Przystań, Miedźno, Biała, Zuraw, Nakło, Cmińsk, Baczkowice (AKMKr: Vis. 27, s. 110).

99 Korytnica, Brzeziny, Swierze, Potok, Goleniowy, Wsola, Kliczanów, Wieżownica, Strzyżowice, Łagów. 
umierali bez sakramentów świętych ${ }^{100}$. Prawie przy wszystkich zgonach ludzi dorosłych zanotowano, że byli zaopatrzeni sakramentami; w wypadku śmierci bez udzielenia sakramentów proboszcz notował, dlaczego się tak stało ${ }^{101}$. Przeglądając wizytacje i akta sądowe wyczuwa się wielkie uczulenie zarówno władz diecezjalnych jak i kapłanów oraz wiernych na sprawę zaopatrzenia chorych sakramentami świętymi. Wizytatorzy zwracali baczną uwagę na zaniedbania w tym zakresie, a sprawy poważnych zaniedbań oddawali do sądów kościelnych, gdzie je rozpatrywano i udzielano napomnień i kar. W r. $1735 \mathrm{w}$ sądzie diecezjalnym w Krakowie rozpatrywano zgon dwu kobiet z Olkusza nie zaopatrzonych przed śmiercią sakramentami św. ${ }^{102} \mathrm{~W}$ r. 1738 sąd biskupi ukarał ks. Tomaszkiewicza, proboszcza z Rybnej, za to, że mimo wezwania nie poszedł do chorego i nie zaopatrzył go św. sakramentami i chory umarł bez posługi kapłańskiej ${ }^{103}$. Także Sąd Oficjała Okręgowego w Radomiu nie przyjął tłumaczenia ks. Jana Klimkowskiego, proboszcza w Suchej, że nie miał czasu pójść do chorych, którzy w jego parafii i z jego winy umierali bez sakramentów św. ${ }^{104} \mathrm{Za}$ zaniedbania w tym względzie wizytator oskarżył przed sądem duchownym proboszczów: ks. Stanisława Chojnackiego z Maciejowic i ks. Józefa Zawadzkiego z Kłoczowa ${ }^{105}$. Podobnie upomniał wikariusza w Łagowie, by szedł do chorych i nie tłumaczył się, że nie przysłano konia ${ }^{106}$.

$\mathrm{Z}$ przedstawionych faktów wynika, że $\mathrm{w}$ zasadzie przestrzegano $\mathrm{w}$ parafiach przepisów biskupich odnoszących się do duszpasterstwa chorych. Nasuwa się więc pytanie, dlaczego bp Lipski ubolewał nad tym, że wierni rzadko przyjmowali sakrament namaszczenia chorych. Wypływa z tego wniosek, że notatka po zgonie ,zaopatrzony sakramentami św." niekoniecznie oznaczała, że zmarły przyjął sakrament namaszczenia chorych. Przeciwnie, takie notatki jak „zaopatrzona sakramentem spowiedzi" lub ,zaopatrzona sakramentem ostatniego namaszczenia" sugerują, że stwierdzenia bpa Lipskiego były prawdziwe: umierający spo-

100 AP Tenczynek: Liber defunctorum ab 1699-1798; AP Łazany: Liber mortuorum. t. 1 , ab A. 1664 , s. $485-489$; J. K r a cik, jw., s. 233; M. L a s k ow ski, jw., s. 104-108; M. A l e k s a d r o w i c z, Z badań nad dziejami religijności wiernych archidiakonatu gnieźnieńskiego $w$ początkach XVIII $w$., „Roczniki Humanistyczne” 24 (1976) z. 2 s. 13.

101 ,.Sacramentis negdum monitus per negligentiam uxioris suae, nisi paenitentia ductus fuerit aput Patres Reformatos ante aliquot dies (AP Eazany: Liber mortuorum, s. 488).

102 AKMKr: AOf 172 (1735), s. 451-454.

103 AKMiKr: AEp 83 (1738), 's. 47.

104 AKMKr: Vis. 24, s. 177 (Sucha).

105 AKMKr: Vis. 24, s. 269 (Maciejowice); Vis. 24, s. 304 (Kłoczów).

106 ,Ad infirmos vero propere sine tergi versatione sub praetextu - vano non adducti qui discedat". (AKMKr: Vis. 27, s. 81). 
wiadali się i przyjmowali komunię św., ale rzadko przyjmowali sakrament namaszczenia chorych ${ }^{107}$.

$\mathrm{Na}$ zakończenie trzeba wspomnieć, że rytuały używane przez kapłanów czy to $\mathrm{z}$ r. 1725 , czy też wydrukowane za rządów bpa Lipskiego w r. 1743 , podawały dokładne przepisy o należytym przygotowaniu mieszkania chorego na przyjście kapłana, o sposobie niesienia olejów św. i szczegółowo określały ceremonie towarzyszące udzielaniu sakramentu namaszczenia chorych ${ }^{108}$.

\section{KAPEAŃSTWO}

Kapłaństwo jest sakramentem społecznym, dlatego łaska i władza płynące $\mathrm{z}$ niego owocują nie tylko $\mathrm{w}$ życiu przyjmującego ten sakrament, ale w całej społeczności kościelnej, dla której kapłan zostaje wyświęcony. Biskupi polscy na synodzie prowincjalnym w Gnieźnie w r. 1628, na początku uchwał dotyczących wyświęcenia duchownych zwracali uwagę na intencje i motywy kierujące kandydatami do święcen ${ }^{109}$. Synod przestrzegał biskupów, by nie święcili kleryków polecanych przez innych duchownych. Lęk przed innymi, chęć łatwego życia, zysków, a nawet próba ucieczki od spraw tego świata - nie mogły być wystarczającymi powodami, by kogoś dopuścić do święceń kapłańskich. Synod wymagał od kandydata do kapłaństwa pragnienia życia w pobożności, czystości, wierności Bogu, posłuszeństwa Kościołowi i gorliwej służby wokół zbawienia innych. Synod żądał nadto od kandydatów do kapłaństwa, by posiadali odpowiednią wiedzę. Dopuszczeni do święceń mniejszych winni umieć czytać, pisać, rozumieć łacinę i znać podstawowe prawdy wiary. Od kandydatów do święceń wyższych wymagano, by byli biegli $\mathrm{w}$ piśmie, mieli brewiarz i umieli go odmawiać oraz by posiadali ogólne wiadomości o sakramentach, szczególnie o kapłaństwie. Wreszcie od kandydata na kapłana oczekiwano umiejętności nauczania ludzi i udzielania sakramentów św. oraz rozeznania w tym, co jest konieczne do zbawienia. Kandydat przed przystąpieniem do święceń miał okazać prawdziwe dokumenty, poświadczające miejsce jego urodzenia, zamieszkania oraz dobre świadectwo od proboszcza i kierownika szkoły wraz $\mathrm{z}$ wiarygodnym poświadczeniem o braku przeszkód do święceń. Nastę-

107 "Sacramento paenitentiae munita" (AP Łazany: Liber mortuorum, 15 III 1745, s. 489); „Die 22 septembris (1735) mortua est Eva Dziubkówna annos circiter 50 sacramento munita Extrema Unctione" (AP Łazany: Liber mortuorum, s. 487). Ciekawe, na jakiej podstawie ks. Marian Aleksandrowicz napisał w swoim artykule takie słowa: „Sakrament namaszczenia był przez wiernych przyjmowany powszechnie" (M. Aleks androwi c z, jw., s. 13).

108 Rituale Sacramentorum Cracoviae 1743, s. 43-63.

109 Synodus provinc. 1628: De ordinatione clericorum. 
pnie synod określił wiek święconych: przyjmujący tonsurę i trzy mniejsze święcenia mieli mieć 7 lat, a akolici 12 rok życia ukończony. Wiek subdiakona określili biskupi na 22 lata, diakona na 23, a kapłana na 25 lat. Między niższymi a wyższymi święceniami powinna być przerwa jednego roku, a w tym czasie kandydaci mieli sumiennie wykonywać obowiązki wypływające z przyjętych już święceń, częściej się spowiadać i przyjmować komunię św. Od kandydata do święceń subdiakonatu synod wymagał podpisanej prawdziwej prowizji (obietnica przyjęcia do pracy duszpasterskiej) lub zabezpieczenia dochodów z fundacji rodzinnych. Przypomniano też biskupom na tym synodzie, że mogli święcić tylko mieszkańców swoich diecezji, a kandydaci z diecezji obcych musieli okazać listy polecające swojego biskupa. Wreszcie ustalił też synod listę przeszkód wzbraniających udzielania święceń.

Bp Lipski w liście pasterskim w poszczególnych pouczeniach rozszerzył zalecenia synodalne. I tak, od przyjmujących tonsurę wymagał, by byli bierzmowani; od kandydatów do święceń niższych wymagał noszenia stroju duchownego i tonsury oraz studiów w seminarium lub w uniwersytecie $\mathrm{w}$ celu zdobycia odpowiedniej wiedzy. $\mathrm{Na}$ odpowiednią wiedzę bp Lipski kładł ogromny nacisk, ponieważ ,niewiedza kapłana w najwyższym stopniu dla dusz wiernych jest szkodliwa". Zakres wiedzy teologicznej obejmował sakramenty św., ich cel i ustanowienie przez Chrystusa. Szczególną jednak troską bpa Lipskiego było, by kandydaci na kapłanów umieli dobrze spowiadać. W tym celu, w rozdziale szóstym swego listu pasterskiego nakazał egzaminatorom prosynodalnym pytać o wiadomości $\mathrm{w}$ zakresie władzy i przymiotów spowiednika oraz poszczególnych warunków sakramentu pokuty i kar kościelnych. W żadnym wypadku nie wolno im było dopuścić do święceń kandydata, który nie posiadał wymaganych wiadomości. Kandydaci musieli odpowiedzieć na postawione pytania (wzór tych pytań biskup podał) dotyczące żalu za grzechy, spowiedzi, zadośćuczynienia, rozgrzeszenia, tajemnicy spowiedzi i restytucji ${ }^{110}$.

Zobaczmy teraz, jak w praktyce udzielano sakramentu kapłaństwa w diecezji krakowskiej w czasie rządów bpa Lipskiego. Głównym szafarzem tego sakramentu był sam bp Lipski ${ }^{111}$. Osobiście wyświęcił on 319 kapłanów, 276 diakonów, 277 subdiakonów. Święceń mniejszych i tonsury udzielił 211 klerykom. Za zgodą bpa Lipskiego święcił w diecezji krakowskiej również biskup pomocniczy Michał Kunicki. Z księgi jego czynności pontyfikalnych dowiadujemy się, iż wyświęcił 957 diakonów na kapłanów, 935 kleryków otrzymało z jego rąk diakonat, a 951 sub- 
diakonat. Święceń niższych i tonsury udzielił 1159 osobom ${ }^{112}$. Na mocy specjalnego pozwolenia bpa Lipskiego $\mathrm{w}$ omawianych czasach udzielali święceń w diecezji krakowskiej także inni biskupi: Franciszek Kobielski - biskup łucki ${ }^{113}$, Józef Antoni Łodziński - biskup pomocniczy inflancki ${ }^{14}$, Wacław Hieronim Sierakowski - biskup inflancki, kamieniecki, a później przemyski i lwowski ${ }^{115}$, oraz Stanisław Rajmund Jezierski - biskup bakowski ${ }^{116}$. Swięcenia odbywały się zasadniczo w katedrze wawelskiej, choć niektórzy biskupi święcili też w innych kościołach krakowskich (św. Piotra i Pawła), a także poza Krakowem: w Tarnowie (1734), Lublinie (1739) i Słupi (11 XI 1744) ${ }^{117}$. Swięceń udzielano przeważnie $\mathrm{w}$ suchedni albo $\mathrm{w}$ sobotę przed niedzielą Męki Pańskiej. W przypadkach udzielania święceń w inne dni korzystano z dyspensy, której mógł udzielać bp Lipski na mocy uprawnień danych mu przez Stolicę Apostolską dnia 5 lutego $1733^{118}$. Przed święceniami urządzano egzamin w zakresie dyscyplin teologicznych, o czym świadczą notatki w księdze święceń. Dnia 21 września 1737 r. nie dopuszczono do święceń pięciu diakonów (dwóch zakonnych i trzech diecezjalnych), dwóch subdiakonów i trzech minorzystów z powodu niedostatecznej wiedzy ${ }^{119}$. W tym samym dniu nie dopuszczono do święceń jednego subdiakona, ponieważ nie przedstawił swiadectwa zdrowia. Dnia 21 grudnia 1737 r. odmówiono święceń dwom kandydatom do kapłaństwa i czterem do subdiakonatu również z powodu braku odpowiedniej wiedzy ${ }^{120}$. W jednym przypadku warunkowo wyświęcono Marcina Długoszewskiego na kapłana w dniu 20 kwietnia 1737 r., z zastrzeżeniem, że będzie

112 AKMKr: Liber ordinatorum ... Kunicki), s. 160-387.

113 Franciszek Antoni Kobielski, s. Mikołaja i Teresy Tarnowskiej, ur. 1679, zm. 1755, biskup antynopolitański, sufragan włocławski, biskup kamieniecki i łucki; zob. W. Szczygi elski, [w:] Polski Stownik Biograficzny, t. 11, s. 211.

114 Józef Antoni Łodziński O.F.M. Conv., biskup gerazeński z obowiązkiem przebywania w Inflantach, odbywania misji i pełnienia funkcji biskupich za zgodą ordynariusza; - zob. Z. Szostkiewicz, Katalog biskupbw obrz. łac. przedrozbiorowej Polski, [w:] Sacrum Poloniae Millenium, t. 1, Rzym 1954, s. 504.

115 Wacław Hieronim Sierakowski (1699-1780), biskup inflancki, kamieniecki, przemyski i arcybiskup lwowski; - zob. Z. Szostkiewicz, jw., s. 554.

116 Stanisław Rajmund Jezierski, s. Krzysztofa i Teresy Cieciszewskiej (1698-1782), biskup bakowski w Mołdawii, wykładal filozofię na Studium Generalnym OO. Dominikanów w Krakowie; - zob. J. R e y chma n, [w:] Polski Stownik Biograficzny, t. 13, s. 146-148.

117 AKMKr: Liber ordinatorum..., s. 223-224 (Tarnów), 301-302 (Lublin), 367 (Słupia).

118 AKMKr: AEp 82, s. 162-165.

119 AKMKr: Liber ordinatorum, s. 275: Reiecti in hoc egzamine: diakoni Krzysztof Strzedulski, Jakub Krulikowski, Józef Pietrzykowski, Michał Krzeczkowski, Michał Kurski; subdiakoni - Franciszek Latosiński, Jan Maszczulski (brak świadectwa zdrowia); minorzyści - Ignacy Sędzimir, Wawrzyniec Cosiński, Jan Mendelewski.

120 AKMKr: Liber ordinatorum, s. 278: diakoni - Szymon Krzywodowski, Tomasz Kotliński; minorzyści - Wawrzyniec Cuszyński, Jakub Chochrewski, Jan Karasiewicz, Franciszek Janes. 
mógł spowiadać dopiero po upływie dwóch lat ${ }^{121}$. Dwuletni pobyt w seminarium pomagał zdobywać moralne przygotowanie do święceń. Usuwanie kleryków ze seminarium z powodu złego ich prowadzenia się może przekonywać, że na cnoty i dobre obyczaje kandydatów też zwracano uwagę. Jeśli urząd i władza święceń udzielone kapłanom przez święcenia w duszpasterstwie diecezjalnym odgrywały olbrzymią rolę, to sam obrzęd święceń nie miał wielkiego znaczenia duszpasterskiego. Święceń udzielano bowiem w dnie powszednie, przy niewielkim udziale wiernych, a same obrzędy były ogółowi nieznane i niezrozumiałe ${ }^{122}$.

\section{MAモZEŃSTWO}

Podobnie jak sakrament kapłaństwa, tak małżeństwo jest sakramentem społecznym. Sobór Trydencki sprecyzował naukę Kościoła o małżeństwie ${ }^{123}$. Na synodzie prymacjalnym w r. 1628 biskupi przyjęli Pastoralna kard. Maciejowskiego i ogłosili szczegółowe przepisy tyczące się małżeństwa. Zwrócili więc uwagę na wielkość tego sakramentu, określili jego cel, a więc przekazywanie życia i wychowywanie dzieci. Według biskupów związek małżeński miał być związkiem wolnym i zawartym za wzajemną zgodą. Przeszkodami dla ważności małżeństwa były: porwanie narzeczonej oraz pokrewieństwo i powinowactwo tak fizyczne jak i duchowe. Biskupi nakazali głosić zapowiedzi w następujące po sobie trzy niedziele i święta na mszach uroczystych w celu zapewnienia ważności tego sakramentu, natomiast wiernych zobowiązywali do powiadomienia proboszcza o przeszkodach. Szczególnie baczną uwagę mieli zwracać proboszczowie na przybyszów i ludzi im nieznanych. Aby małżeństwo było owocne w łaskę Bożą, proboszczowie winni zachęcać narzeczonych do spowiedzi i komunii św. Synod uzależnił ważność małżenstwa od wyrażenia przez narzeczonych zgody na nie przed proboszczem i dwoma świadkami. O zawarciu małżeństwa proboszcz powinien zanotować w Księgach zaślubionych ${ }^{124}$.

Powyższe przepisy były znane w diecezji krakowskiej, albowiem ogłaszali je poprzednicy bpa Lipskiego na synodach diecezjalnych: bp Marcin Szyszkowski w r. 1620, bp Kazimierz Eubieński w r. 1711 oraz bp Konstanty Szaniawski w liście pasterskim z 1720 r. ${ }^{125}$ Te przepisy

121 AKMKr: Liber ordinatorum, s. 265.

$122 \mathrm{D}$. S y nowiec, Życie religijno-moralne $w$ diecezji przemyskiej $w$ XVII i XVIII w., "Nasza Przeszłość” 43 (1975) s. $1-89$.

123 Trid. e ref. ses. 24: Doctrina de sacramento matrimonii; W. Schenk, jw., s. $123-152$.

124 Synodus prov. Gnesn. 1628: De matrimoniis.

125 RGSz: De matrimonio; SE: De matrimonio; ESz: De matrimonio. 
były wydrukowane również w rytuałach z r. 1725 i 1743, którymi posługiwali się duchowni przy udzielaniu sakramentów świętych.

Bp Lipski poświęcił małżeństwu sporo miejsca w swym liście pasterskim. „Ponieważ wszystkie sakramenty - pisał - tak w udzielaniu jak i przyjmowaniu wymagają stanu łaski, tak też małżeństwo do jego godności przez Chrystusa Pana podniesione nie mniejszej łaski, szacunku i czystości sumienia od innych wymaga". Zobowiązywał przeto duszpasterzy, by głosili zapowiedzi oraz zakazał błogosławić małżeństwa, gdy narzeczeni nie znali prawd wiary oraz nie wiedzieli, jakie są przeszkody zrywające małżeństwo. Baczniejszą uwagę zwracał na ludzi prostych i chłopów; polecił ich egzaminować ze znajomości modlitw Ojcze nasz, Zdrowaś Maryjo, Wierze w Boga, Chwała Ojcu a także 10 przykazań Bożych i 7 Sakramentów świętych. Przypominał też rodzicom o obowiązku nauczania dzieci tego wszystkiego, co dotyczy sakramentu małżeństwa.

Następna uwaga duszpasterska odnosiła się do pory błogosławienia małżeństw. „Duszpasterz powinien dbać - pisał bp Lipski - by, o ile to możliwe, błogosławić małżeństwa rano, bo narzeczeni mogą być na mszy św., przystąpić do spowiedzi i komunii świętej”. Dawał też szczegółowe wskazania, jak miał postępować proboszcz wobec przybyszów i nieznajomych: winien wymagać dokumentów chrztu św. oraz poręczenia dwóch wiarygodnych świadków, że nie ma przeszkód małżeńskich między narzeczonymi. Na zakończenie zobowiązywał w sumieniu proboszczów do zawiadamiania władz kościelnych o małżeństwach żyjących w separacji ${ }^{126}$. Powyższe nakazy i pouczenia bp Lipski uzupełnił listem Editum super denuntiationibus z dnia 20 lipca 1743 r. Nawiązując do wskazań papieskich, nakazywał, by ze względu na społeczną ważność sakramentu małżeństwa proboszcz osobiście spełniał czynności związane z przygotowaniem tego sakramentu. Zobowiązywał więc proboszczów, by przeprowadzali przedślubne badania, podczas których mieli pytać narzeczonych oddzielnie o dobrowolną zgodę, czy nie zachodzą przeszkody zrywające, oraz odebrać oświadczenie, że nie obiecywali nikomu innemu małżeństwa i pobierają się za zgodą rodziców. Dopiero po takim badaniu mógł proboszcz głosić zapowiedzi. Powołując się na postanowienia papieża Benedykta XIV (1740-1758), zobowiązał proboszczów, by $\mathrm{w}$ prośbach o dyspensę od zapowiedzi podawali przyczyny kanoniczne i dopiero po jej uzyskaniu proboszcz miał ogłosić zapowiedzi dyspensowe - po błogosławieniu małżeństwa. Uczulał bardzo proboszczów na przeszkody małżeńskie i polecał, by starali się je usuwać zanim małżeństwo będzie zawarte ${ }^{127}$.

${ }^{126}$ ELip: De sacramento matrimonii.

127 Edictum super denuntationibus, Kraków 20 VII 1743. 
$\mathrm{W}$ praktyce duszpasterskiej zgodnie z przepisami kanonicznymi małżeństwa błogosławił proboszcz narzeczonych. Zdarzały się wyjątki, ale były one nieliczne. W wizytacjach wybranych 10 dekanatów tylko w parafii Przystań (dek. Lelów) wizytator nakazał proboszczowi Andrzejowi Monowiczowi, by podał do sądu Jana Pieniążka, który zawarł małżeństwo w innej parafii bez zgody proboszcza ${ }^{128}$. W krakowskim sądzie kościelnym na 49 rozpraw w 7 przypadkach unieważniono małżenstwo z powyższego tytułu.

Z braku dostatecznych źródeł nie można wystarczająco dokładnie przedstawić, jak praktycznie proboszczowie przeprowadzali przedślubny egzamin i sporządzali odpowiedni protokół. Pewne światło na ten problem rzucają sprawy sądowe rozpatrywane w sądzie konsystorskim w Krakowie. Wynika z nich, że proboszczowie nie przywiązywali zbytniej wagi do pytania narzeczonej o dobrowolność decyzji wstąpienia w związek małżeński. Prawie połowa ubiegających się małżeństw o stwierdzenie nieważności ich związku, jako przyczynę podawała siłę i przymus ze strony już to rodziców, już też narzeczonego. Na 49 rozbitych małżeństw aż 21 zawartych było pod przymusem. Można także stwierdzić, że proboszczowie nie pytali wnikliwie o stopień pokrewieństwa, gdyż w siedmiu przypadkach małżonkowie byli krewnymi i zawarli małżeństwo bez uzyskania dyspensy, więc sąd biskupi orzekł ich nieważność. Zdarzało się, że proboszczowie błogosławili małżeństwa, nie wiedząc, czy narzeczeni są ich parafianami. Wydaje się jednak, że zabiegi i starania bpa Lipskiego o poprawienie tego stanu nie były bezskuteczne, jako że po ogłoszeniu listu pasterskiego o zapowiedziach przedślubnych proboszczowie zaczęli przykładać większą wagę do badania przedślubnego narzeczonych. Np. w Łazanach w Księdze zaślubionych załączono świadectwo moralności, którego zażądał tamtejszy proboszcz od narzeczonego urodzonego w Wieliczce, gdzie się wychował, a żenił w Łazanach ${ }^{129}$. Przeglądnięcie metryki zaślubionych w parafii mariackiej w Krakowie oraz w Tenczynku i Eazanach przekonuje, że zapowiedzi były głoszone przez trzy następujące po sobie niedziele i święta. Z dyspens korzystała tylko szlachta oraz bogaci mieszczanie. W parafii Łazany wszystkie śluby poprzedziło głoszenie zapowiedzi, a w Tenczynku tylko raz udzielono dyspensy od jednej zapowiedzi (1743 r.). W parafii mariackiej w Krakowie do r. 1743 korzystano z większej liczby dyspens niż

128 AKMKr: Vis. 26, s. 115.

129 „Niżej podpisany daję to testimonium od kościoła farnego naszego wielickiego Panu Józefowi Zydrychowi w Wieliczce narodzonemu i wychowanemu zacnie i poczciwie w swoim młodzieństwie zachowującemu się, a ponieważ zaś w tamecznej farze Łazany contraxit domicilium ad contrahendum matrimonium, przeto pro et cum eo suplikuję, quatenus compos voti sui efficiatur. Anno Domini 1745". (AP Łazany: Liber copulatorum, s. 425). 
po roku 1743. Dla ilustracji warto przytoczyć, że w r. 1735 na 97 ślubów 5 błogosławiono z dyspensą od jednej zapowiedzi, 13 od dwóch zapowiedzi, a trzecią głoszono w czasie ślubu, zaś trzem parom małżeńskim udzielono dyspensy od trzech zapowiedzi. Podobne proporcje były w roku 1736. Natomiast w r. 1744 na 60 zawartych małżenstw było tylko $5 \mathrm{dy-}$ spens od jednej zapowiedzi, jedna od dwóch zapowiedzi i ani jednej od trzech. W latach 1745 i 1746 proporcje kształtowały się podobnie, co potwierdza opinię, że po ogłoszeniu listu poprawiła się pod tym względem sytuacja $^{130}$.

Czas zawierania małżeństw był ściśle zachowywany: nie błogosławiono małżeństw w Adwencie od pierwszej niedzieli do 6 stycznia, a w Wielkim Poście od środy Popielcowej do Niedzieli Białej. Wielką pomocą dla duszpasterzy był ponownie wydany w Krakowie w r. 1743 rytuał piotrkowski, który oprócz obrzędu błogosławienia małżeństw zawierał dokładne przepisy odnoszące się do sakramentu małżeństwa ${ }^{131}$. Wydrukowano w nim wzór głoszenia zapowiedzi, pouczenie, jak należy przeprowadzać badania przedślubne oraz załączono wzór zapisu metrykalnego. Obrzęd błogosławienia małżeństw podany był $\mathrm{w}$ trzech językach: polskim, niemieckim i litewskim.

Metryki zaślubionych oraz rozprawy sądowe w sprawach małżeńskich rzucają pewne światło na zawierających sakrament małżeństwa. Wierni niższego stanu, chłopi i ubodzy mieszczanie, nie ubiegali się o dyspensy od zapowiedzi, co pomagało wykrywać przeszkody zrywające i zapewniało ważność związku. Wypadki stwierdzenia nieważności małżeństwa wśród chłopów były bardzo rzadkie ${ }^{132}$. W rodzinach bogatych mieszczan, szlachty i magnatów najczęściej nie liczono się $\mathrm{z}$ wolą narzeczonej i stosowano przymus. W tych warstwach społecznych zdarzały się też porwania narzeczonej. Przypadki zawierania małżeństwa $\mathrm{z}$ narzeczoną, która złożyła ślub czystości oraz stawianie warunków osobie mającej być zaślubioną, świadczą o słabej znajomości przepisów prawa małżeńskiego. Przyczyny podawane w sądzie, jak: złe traktowanie małżonki, bicie jej, poniewieranie oraz surowość mężów (5 przypadków na 49 rozpraw) nasuwają wniosek, że pożycie ówczesnych małżeństw nawet $\mathrm{w}$ sferach wyższych nie było za dobre. Na zakończenie podam dane liczbowe dotyczące kręgów społecznych, z których pochodzili małżonkowie związków rozbitych. Na 49 małżeństw 31 było szlacheckich, 11 magnackich, 3 mieszczańskie, a tylko jedno pracownika fizycznego.

130 Archiw. Archipr. Kościoła N.P. Maryi w Krakowie: Metrica copulatorum 1722-1756.

181 Rituale sacramentorum, Cracoviae 1743, s. 23-32.

132 AKMKr: AOf 173, s. 186 (małżeństwo Szeremak i Magdalena Szwedzianka). 


\section{POSWIĘCENIA, BEOGOSEAWIENSTWA, POGRZEBY}

Sakramentalia (taką nazwą określa się poświęcenia, błogosławieństwa i pogrzeby) uzupełniały i wzbogacały życie religijne wiernych. Biskupi polscy na synodzie prymacjalnym w Gnieźnie przyjęli naukę kard. Bernarda Maciejowskiego ( $\dagger 1608)$ o sakramentaliach, ceremoniach i walce $\mathrm{z}$ ich nadużyciami, ogłoszoną w Pastoralnej ${ }^{133}$. Pouczali wiernych, że jest rzeczą pożyteczną korzystać z poświęceń, błogosławieństw i innych ceremonii kościelnych. Upominali wiernych, by w odpowiednim czasie i według przepisów Kościoła czy zwyczaju prowincji poświęcali sól, wodę, wino, owies, złoto, kadzidło, mirrę, świece, palmy, ogień, pokarmy i zioła. Poświęconych rzeczy zakazywali używać dla zabobonu. Ceremonie te i poświęcenia powinny być dokonywane według rytuału piotrkowskiego. Zabraniano urządzania procesji wokół chrzcielnicy, przestrzegano przed nadużyciami w czasie procesji kapników, zakazywano obnoszenia obrazów po polach i zrzucania z belek i pował kościelnych podobieństw demonów w dzień Wniebowstąpienia Pańskiego. Biskupi przestrzegali również przed braniem udziału w obrzędach ludowych odprawianych na św. Jana uzasadniając, że one odwracają ludzi od tajemnic odkupienia, a zwracają do zabaw. Dużo miejsca poświęcono błogosławieniu domów w okresie świąt Bożego Narodzenia. Poświęcenie to nazywano kolędą i - według zaleceń synodu - duszpasterze mieli zaczynać kolędę 1 stycznia i kończyć przed rozpoczęciem Wielkiego Postu. Czynności związane $\mathrm{z}$ nawiedzeniem parafian były bardzo ściśle określone; proboszcz sam lub jego zastępca udawał się do poszczególnych domów parafian dla celów pobożnych, a nie dla zysku. Przy wejściu pozdrawiał mieszkańców słowem Bożym, po czym udzielał błogosławieństwa. Zwoławszy wszystkich mieszkańców pouczał o prawdach wiary koniecznych do zbawienia i sprawdzał, czy domownicy umieli pacierz (Ojcze nas, Zdrawaś Maryo, Wierzę $w$ Boga, 10 przykazań Bożych i przykazania kościelne). Gdy trzeba było, upominał w sposób łagodny grzeszących i wszystkich zachęcał do praktykowania cnót odpowiednich stanowi i wiekowi domowników. Gdy w domu byli chorzy, miał ich pocieszyć. Powołując się na słowa Jezusa „ci, co ewangelię głoszą z ewangelii żyją", pozwalali duszpasterzom brać upominki rzeczowe.

W diecezji krakowskiej za rządów bpa Lipskiego udzielano błogosła-' wieństw. Przekonują o tym teksty poświęceń i błogosławieństw umieszczone w Rytuale piotrkowskim, wydanym w Krakowie w r. $1743^{184}$. Również rubrycele, drukowane $\mathrm{z}$ roku na rok, przypominały duszpa-

183 Synodus prov. 1628: De sacramentalibus, caeremonialibusque et abusu illorum tollendo.

184 Rituale sacramentorum 1743 , s. 58-108. 
sterzom, kiedy i co mają poświęcać ${ }^{135}$. Bp Lipski nie zajmował się osobno sakramentaliami, jedynie w niektórych rozdziałach swego listu pasterskiego wspominał o nich. I tak wymienia błogosławieństwo matek po urodzeniu dziecka oraz błogosławieństwo panny młodej po ślubie, nakazując księżom, by przy tej okazji brali ofiary, jakie im z dobrej woli złożą petenci ${ }^{136}$. Polecił również, by proboszczowie wedle zwyczaju dokonywali błogosławieństwa domów w okresie Bożego Narodzenia ${ }^{137}$.

Do obrzędów liturgicznych należy pogrzeb. Zarówno rodzina, jak i duszpasterze byli zobowiązani prawem miłości urządzić zmarłemu pogrzeb chrześcijański i modlić się za jego duszę. Przepisy pogrzebowe, bardzo szczegółowo określone przez kard. B. Maciejowskiego w Pastoralnej, przyjęli biskupi na synodzie prymacjalnym w r. 1628; zachęcali więc proboszczów, by dowiedziawszy się o zgonie parafianina modlili się za niego. Proboszczowie mieli także wpływać na rodzinę, by nie trzymała zbyt długiego ciała zmarłego bez pochówku. Obrzęd pogrzebowy nakazywali biskupi duszpasterzom odprawiać według Rytuału piotrkowskiego, a w mowach pogrzebowych przypominać prawdy ostateczne. Zwracali się do wiernych, by ograniczali wydatki na zbyt okazałe pogrzeby i zachęcali ich do zamawiania raczej mszy św. za zmarłych i dawania jałmużny ubogim. Ponieważ nie wszyscy wierni zasługiwali na pogrzeb chrześcijański, biskupi wymienili szczegółowo, komu i z jakich powodów należało odmówić pogrzebu kościelnego ${ }^{133}$.

Bp Lipski poświęcił pogrzebom dużo miejsca w swoim liście pasterskim. Pominął wiele przepisów Pastoralnej i synodu prymacjalnego z r. 1628, a zwrócił uwagę głównie na sprawy finansowe, które bywały przyczyną wielu sprzeczek, niezgód i zgorszenia. Nieporozumienia te zachodziły często między proboszczem a zakonami. W celu zapobieżenia im bp Lipski polecał, by pogrzeby zmarłych, którzy przyjęli sakramenty św., odbywały się w kościolach parafialnych. Szczególowe przepisy wydał również na temat pogrzebów w kościołach klasztornych; nie wolno było zakonnikom zacząć pogrzebu, dopóki rodzina lub spadkobiercy nie zapłacili proboszczowi czwartej części sumy złożonej na pogrzeb. Chcąc następnie zapobiec sprzeczkom i zgorszeniom zỏarzającym się pomiędzy proboszczami a wiernymi, określił wysokość opłat, jaką mogli proboszczowie żądać za posługę pogrzebową. Wyszczególnił kwoty, które mogli brać za przyprowadzenie zmarłego z domu do kościoła. Opłaty za obrzędy w kościele (śpiewy i msze św.) uzależnił od mniej lub bardziej uroczystego odprawiania. Kondukt i Salve Regina dla wszystkich kosztował jeden złoty. Cena za miejsce w kościele była wyższa niż na

${ }_{135}$ Rubricella Dioecesis Crac. iuxta rubrices generales Breviarii et Missalis Romani, ac decreta S. Rit. Congregat. 1735 , vol. 1 ; 1738, vol. $2 ; 1745$, vol. 3 .

${ }_{136}$ ELip: De accidentiis parochorum, obventionibus et taxa. 
cmentarzu. Wyznaczył też wysokość opłat za czynności towarzyszące obrzędowi pogrzebowemu, jak dzwonienie, okrycie trumny całunem, palenie świec. Prawdziwym ubogim - pisał bp Lipski - proboszczowie ze względu na miłosierdzie i pobożność powinni urządzać pogrzeby za darmo. Podobnemu celowi (uniknięcie nieporozumień) służyło szczegółowe oraz dokładne wymienienie przez biskupa przypadków, w których proboszcz mógł odprawić pogrzeb tylko za pozwoleniem władzy kościelnej ${ }^{139}$.

Przepisy bpa Lipskiego okazały się bardzo aktualne, gdyż w tych czasach do obrzędu pogrzebowego przywiązywano wielką wagę, zaś dla duchownych diecezjalnych i zakonnych obrzędy te stanowiły ważne źródło dochodu. Ceremonie pogrzebowe były bardzo uroczyste i dobrze opłacane, zwłaszcza gdy urządzali je ludzie bogaci. Proboszczowie, zakonnicy, klerycy, bractwa, służba kościelna oraz biedni wynosili korzyść z każdego pogrzebu, byli bowiem zamawiani i opłacani przez rodzinę zmarłego. Szczególnie uroczyste pogrzeby odprawiali możnowładcy. Trwały one nieraz po kilka dni, a nawet tygodni. Naśladowali ich bogaci mieszczanie. Takie pogrzeby, zwłaszcza magnackie, były wspaniałymi widowiskami. Kuchowicz pisze, że „na pogrzeb udawała się niemal cała ludność wsi, odprowadzając zmarłego na miejsce spoczynku" ${ }^{140}$. Sam bp Lipski uczestniczył $\mathrm{w}$ trzech uroczystych pogrzebach magnackich. W r. 1742 odprawił pogrzeby: Antoniego Ponińskiego, Marka Szembeka i Rozalii Gordonowej. Wszystkie odbyły się w kościele reformatów w Krakowie ${ }^{141}$. Magnatów, szlachtę, bogatych mieszczan i chłopów grzebano $\mathrm{w}$ podziemiach kościołów, innych zaś na cmentarzach. W księdze zmarłych parafii Łazany proboszcz zaznaczał, w jakim miejscu cmentarza był grób zmarłego. Zdarzały się wypadki, że dzieci nie ochrzczone chowano pod figurą ,na osobnym miejscu, a zmarłych w 1737 r. na zarazę $\mathrm{w}$ zbiorowych grobach w lesie lub na polach" ${ }^{142}$. W większości przypadków pogrzeby odbywały się w kościele parafialnym; odprawiał je proboszcz lub wikariusz. W przypadku, gdy zmarły życzył sobie pogrzebu w kościele klasztornym, członkowie jego rodziny lub spadkobiercy zgłaszali to proboszczowi. Nie zawsze jednak załatwiano sprawy polubownie, niektóre przypadki trafiały do sądów kościelnych ${ }^{143}$.

Koszty pogrzebów były bardzo zróżnicowane, choć w większości po-

\footnotetext{
187 ELip: De administratione sacramentorum, CA.

${ }^{188}$ Synodus prov. 1628; De funeribus et suffragiis pro defunctis.

189 ELip: De quarta funeralium.

$140 \mathrm{Z}$. K u ch ow ic z, jw., s. 201.

141 J. Pasiecznik, jw., s. 148 (przyp. 9).

142 J. K r a c ik, jw., s. 242.

148 AKMKr: AEp 82, s. 98/17 II 1736 - Daleszyce; s. 108/ 24 II 1736 - Jedlna; AOf 177 , s. 232-233/16 VI 1742 - Oświęcim.
} 
bierano je według taksy iura stolae bpa Lipskiego. Pogrzeby magnackie pochłaniały ogromne sumy; podobnie drogie były pogrzeby bogatych mieszczan ${ }^{144}$. Dla przykładu warto przytoczyć, że 15 kwietnia $1737 \mathrm{r}$. pogrzeb radcy miejskiego $\mathrm{w}$ kościele mariackim $\mathrm{w}$ Krakowie kosztował 616 zł 20 gr. a pisarza Szeligowskiego w tym samym czasie 26 zł $10 \mathrm{gr}^{145}$. Sprawy te wymagały uregulowania, nic też dziwnego, że bp Lipski w liście pasterskim umieścił taksę iura stolae. Ludwik Zarewicz tak ocenił działalność bpa Lipskiego w tej dziedzinie: „,...] oddać mu jednak trzeba słuszność, iż celem zapobieżenia dotychczasowym nadużyciom duchowieństwa przepisał stałą normę w pobieraniu praw stuły" ${ }^{146}$. Przepisy i opłaty pogrzebowe były stosunkowo niskie, cały bowiem pogrzeb kosztował tylko 7 zł i 12 gr, gdy np. na aniwersarz w r. 1737 dawano w kościele mariackim 10 zł 15 gr. Podobnie apel biskupa, by proboszczowie chowali zmarłych biednych za darmo, przyczyniał się do spokoju i ładu w parafiach. Wprawdzie wizytatorzy informowali czasem, że w niektórych parafiach były nieporozumienia na tle żądania większych opłat za usługi pogrzebowe, ale nie precyzowali, o jakie usługi chodziło ${ }^{147}$. Można przypuszczać, że w diecezji krakowskiej znalazło się więcej proboszczów podobnych do duszpasterza w Eazanach, który w ciągu 15 lat (1734-1746) na 66 pogrzebów -8 odprawił za darmo ${ }^{148}$.

\section{KULT SWIĘTYCH, PIELGRZYMKI}

Kontakt duchowy ze świętymi (modlitwa), oddawanie im czci i naśladowanie ich życia - oto owoc wiary w „świętych obcowanie”. Badacze obyczajów XVIII-wiecznych: Bystroń, Kuchowicz, ks. Kracik, w swoich opracowaniach stwierdzają bardzo bliski związek, kształtujący się na wzór ziemski, jaki zachodził między ludźmi wierzącymi a Swiętymi ${ }^{149}$. Boga, Trójcę Swiętą, Rodzinę Swiętą porównywano do dworów pańskich. Ten dwór nièbieski otaczali święci, a który z nich był najbliżej tronu,

144 W roku 1744 pogrzeb Hiacynty Zajfert kosztowal 3.000 zl i 1000 zl za żałobę, w r. 1744 pogrzeb Fr. Toryjani, ,gdy ciało stać będzie w kamienicy pod karpiem, ma się w każdy dzień $100 \mathrm{Mszy}$ św. odprawiać na co pieniądze pozostawiam 2.500 na pogrzeb i 2.500 na rocznicę. W tydzień po pogrzebie ma być sprawiony obiad dla 25 ubogich i oprócz tego każdemu ma być dane po 15 groszy" (J. W. Smoniewski, Wiadomości historyczno-statystyczne o kościele archipresbiterialnym N.M.P. przy rynku w Krakowie, Kraków 1868, s. 125).

145 Archiw. Archipr. Kościoła N.P. Maryi w Krakowie: Rejestr opłat pogrzebowych, vol. 590 .

${ }^{146} \mathrm{~L}$. Zarewicz, Biskupstwo krakowskie $z$ poczetem swych pasterzy, Kraków 1880, s. 56.

${ }_{147}$ AKMKr: Vis. 26, s. 147 (ks. Jan Wodecki - Biała), 140 (ks. Jan Kosmecki Kłobucko), 128 (ks. Tomasz Bykowski - Miedźno).

148 AP Łazany: Liber mortuorum, s. 485-489.

149 J. By stroń, jw., s. 305-309; Z. K u ch ow ic z, jw., s. 100-113; J. Krac i k, jw., s. 246 . 
miał największe możliwości; dlatego powszechnie zanoszono do nich modły, by $u$ tronu Bożego upraszali pomoc we wszystkich ludzkich potrzebach. Społeczności cechowe i zawody miały swoich patronów, do których się zwracano z prośbami w sprawach pracy zawodowej. Chorzy, zależnie od rodzaju choroby, prosili poszczególnych świętych o zdrowie. Gdy kraj nawiedzała zaraza, wzywano powszechnie św. Antoniego, Rocha i Sebastiana, by chronili kraj przed tym nieszczęściem. Różne też były formy czci oddawanej świętym; budowano kościoły pod ich wezwaniem, stawiano ołtarze ku ich czci, rzeźbiono figury i malowano obrazy z ich wyobrażeniem. Szczególnie czczono pośmiertne szczątki świętych, czyli relikwie, które umieszczano w prześlicznych trumnach lub relikwiarzach. W każdym ołtarzu, przy którym odprawiano mszę św. musiały być relikwie świętych męczenników. W dni patronalne danego świętego wystawiano na widok publiczny jego relikwie, a ludzie przychodzili nieraz z daleka, by oddać cześć temu świętemu. Wielkość kultu poszczególnych świętych zależała głównie od propagatorów tej czci. Szczególnie umieli to robić zakonnicy przez urządzanie pielgrzymek, procesji i różnych nabożeństw.

Bp Lipski nie wypowiadał się bezpośrednio na temat kultu świętych; pośrednio jednak określał, jaką cześć mieli odbierać święci w modlitwach brewiarzowych i obrzędach kościelnych. Czynił to przez wydawanie rubryceli, w której dokładnie określał ryt, w jakim należało czcić świętego. Zachowały się rubrycele krakowskie z lat 1735, 1738 i 1742 . Dowiadujemy się z nich, że spośród świętych największą czcią cieszyła się Najświętsza Maryja Panna. W ciągu roku obchodzono uroczyście siedem świąt maryjnych. Swięto Wniebowzięcia (15 sierpnia) miało ryt pierwszej klasy z oktawą, pozostałe były świętami drugiej klasy bez oktawy. Na czele świętych Pańskich stali: św. Jan Chrzciciel, św. Józef, św. św. apostołowie Piotr i Paweł, św. Szczepan i św. Wawrzyniec. Wszystkim im oddawano cześć pierwszej klasy w dniu święta i wspominano przez osiem dni. Pozostali apostołowie oraz św. Michał Archanioł i Młodziankowie odbierali cześć pierwszej klasy. Obrzędy kościelne określane mianem „duplex” przynależały św. Agnieszce, Marii Magdalenie, Annie, Katarzynie, św. Marcinowi i Mikołajowi. Sposób uczczenia wymienionych świętych został uregulowany dekretem Swiętej Kongregacji w dniu 1 grudnia 1742 r. Przepisy liturgiczne szczególną uwagę poświęcały świętym i błogosławionym Polakom. Przewodził im św. Stanisław Biskup i Męczennik, który miał dwa święta w roku (8 maja i 27 września). Szczególnie uroczyście obchodzono święto 8 maja, bowiem urządzano wtedy tradycyjną procesję z Wawelu na Skałkę, Swięty Wojciech, Jacek, Stanisław Kostka, Florian oraz bł. Jan Kanty i Kunegunda mieli uroczyste święta pierwszej klasy z oktawą, zaś św. Kazimierz, bł. Salomea, 
bł. Jan z Dukli tylko święta drugiej klasy. Pozostali święci i błogosławieni odbierali cześć zwyczajną w dniu, w którym przypadało ich wspomnienie.

Powyższe przepisy regulowały urzędowo - ze strony Kościoła i bpa Lipskiego - sposób oddawania czci Matce Bożej i świętym. Były też zapewne próbą kontrolowania tego kultu. Można jednak przypuszczać, że pobożność ludu poszerzała i powiększała cześć świętych. Świętym popularnym i lubianym, niezależnie od rytu ich święta, urządzano wielkie uroczystości i to nieraz dwukrotnie w ciągu roku. W czasie nabożeństw ku ich czci wystawiano Najśw. Sakrament, głoszono kazania, grały kapele, zapraszano sąsiednie kościoły z procesjami ${ }^{150}$. Sława obrazów cudownych, rozgłaszanie otrzymanych łask i zdziałanych cudów, zwłaszcza przez zakonników, wpływały na nieurzędową wielkość kultu niektórych świętych.

Z kultem świętych łączy się także nadawanie ich imion przy chrzcie św. W dekanacie nowogórskim najbardziej rozpowszechnione były imiona: Jan, Tomasz, Jakub, Stanisław oraz Regina, Zofia, Anna, Katarzyna i Agnieszka ${ }^{151}$. W parafii mariackiej w Krakowie w r. 1738 wśród patronów dzieci ochrzczonych przewodzi Jan (11 chłopców), tuż za nim byli Stanisław i Józef (po 8 chłopców) i Jan Kanty (7 chłopców). Św. Katarzyna byla patronką 13 dziewcząt, Matkę Bożą (Marianna) i św. Franciszkę obrano za patronki dla 10 dziewcząt. W dalszej kolejności patronkami były święte: Zofia (9 dziewcząt), Agnieszka (6), Regina (5). W parafii Wszystkich Swiętych w Krakowie w tym samym roku (1738) Katarzyna była najpopularniejszym imieniem chrzestnym dla dziewcząt (8), a Kazimierz, Franciszek i Jan dla chłopców (po 6). Biorąc pod uwagę daty chrztów, nasuwa się wątpliwość, czy imię nadawane na chrzcie było wynikiem popularności i kultu danego świętego, czy też zbiegiem okoliczności, ponieważ większość chłopców i dziewcząt dostawało takie imiona, jakie przypadały w dniu urodzenia lub chrztu, albo w miesiącu. Klasycznym tego przykładem jest imię św. Stanisława Kostki. W parafii Wszystkich Swiętych w Krakowie nadawano je chłopcom chrzczonym $\mathrm{w}$ listopadzie, a $\mathrm{w}$ innych miesiącach żaden chłopiec nie otrzymał tego imienia. W parafii mariackiej w r. 1738 na 11 Janów aż 8 było chrzczonych $\mathrm{w}$ czerwcu; podobnie jest $\mathrm{z}$ wszystkimi imionami nadawanymi na chrzcie świętym ${ }^{152}$.

Szczególnym objawem kultu Matki Bożej i świętych była cześć oddawana im $w$ obrazach i figurach. Niektóre $\mathrm{z}$ nich były bardzo stare

150 J. P a siecznik, jw., s. 53.

151 J. Kra c i k, jw., s. 247.

152 Archiw. Archipr. Kościoła N.P. Maryi w Krakowie: Metrica baptisatorum ab 1738, s. 1, 177; AP Wszystkich Swiętych w Krakowie: Baptisatorum ab 1730-1739 . 
i uchodziły za „łaskami słynące”. Na pierwszym miejscu należy wymienić obrazy Matki Bożej na Jasnej Górze w Częstochowie i w Kalwarii Zebrzydowskiej. Jednakże w każdej okolicy były ośrodki kultu maryjnego czy świętych, do których przychodzili z pobliskich parafii ludzie, by się modlić. Obrazy te uroczyście koronowano, ubierano $\mathrm{w}$ sukienki, obwieszano wotami. Cieszyły się one większą czcią niż figury, a nawet relikwie. $\mathrm{Z}$ nimi to wiązały się pielgrzymski odbywane pojedynczo lub zbiorowo. Właśnie pielgrzymki były szczególnym objawem czci dla Matki Bożej i świętych. Podobnie jak w sprawach kultu świętych, także i w sprawie pielgrzymek nie mamy żadnych wskazań duszpasterskich bpa Lipskiego. Badacze tej formy pobożności stwierdzają, że czasy saskie odznaczały się bujnym rozkwitem pielgrzymowania. Do miejsc cudami słynących ciągnęły tłumy pątników ${ }^{153}$. W diecezji krakowskiej pielgrzymowano przede wszystkim do Częstochowy i Kalwarii Zebrzydowskiej, choć zapewne były i inne miejscowości, w których czczono cudowne obrazy czy figury, ale pielgrzymki do nich miały zakres regionalny. $\mathrm{Z}$ terenów Małopolski południowej pielgrzymowano do Częstochowy w zwartych grupach, często z kapłanem na czele i kierownikiem szkoły już na przełomie XVI i XVII wieku. W późniejszym okresie ruch pielgrzymkowy z tych terenów wydatnie wzrósł i w XVIII w. przybrał formę masową ${ }^{154}$. Wierni diecezji krakowskiej, żyjący $w$ czasach bpa Lipskiego, z pewnością pamiętali wspaniałe uroczystości koronacji obrazu Matki Bożej w Częstochowie w r. 1717 i to wydarzenie bezsprzecznie przyczyniło się do wzrostu pielgrzymek ${ }^{155}$. Niestety, brak dokładnych zapisków o ilości pielgrzymów przybywających na Jasną Górę w tym czasie nie pozwala na bardziej szczegółowy opis tego zagadnienia.

Drugim miejscem masowych pielgrzymek w diecezji krakowskiej była Kalwaria Zebrzydowska. Bystroń nazywa ją najwspanialszą i największą kalwarią polską, do której od 300 lat przybywają setki tysięcy pielgrzymów ${ }^{156}$. Do Kalwarii pielgrzymowano dwa razy do roku: na Wielki Tydzień, by uczestniczyć w misteriach Męki Pańskiej oraz na uroczystość Matki Bożej Zielnej, 15 sierpnia. Autor dziejów Kalwarii Zebrzydowskiej pisze, że w początkach w. XVIII liczbę pielgrzymów przybywających na odpust Wnjebowzięcia obliczano na 50-70 tysięcy, a na wszystkie inne święta po 10-30 tysięcy wiernych. W r. 1730 ilość pątników obliczono na 20-30 tysięcy ${ }^{157}$. Niestety i tu, podobnie jak w Czę-

${ }_{153}$ Z. K u c howicz, jw., s. 108; J. By s troń, jw., s. 311.

154 B. Kumor, Austriackie wtadze zaborcze wobec kultu Królowej Polski i pielgrzymek na Jasnq Górę (1772-1809), "Studia Claromontana” 1 (1981) s. 77.

155 S. Szafraniec, Jasna Góra, studium $z$ dziejów kultu Matki Bożej Częstochowskiej, [w:] Sacrum Poloniae Millenium, t. 4, Rzym 1957, s. 55.

156 J. By stroń, jw., s. 310. 179.

157 H. W y czawski, Dzieje Kalwarii Zebrzydowskiej, Kraków 1947, s. 149, 
stochowie, nie ma szczegółowych zapisków na ten temat, zatem i opis pielgrzymek do tego miejsca musi być ogólnikowy. Za czasów bpa Lipskiego były one z pewnością praktykowane. Kronikarz klasztorny zanotował, że w latach 1743, 1744 i 1745 składano wota w cudownej kaplicy Matki Bożej: w r. 1743 pielgrzymi dali 3 sznury prawdziwych pereł i dwa wota srebrne: Jerzy Jonhino ze Śląska ofiarował Matce Bożej srebrne serce, a inny pielgrzym srebrny krzyżyk (r. 1744). Srebrna korona z łukiem srebrnych gwiazd, ofiarowana przez pielgrzymów ze Sląska dla przyozdobienia figury Matki Bożej w r. 1745, świadczy o pielgrzymkach przybywających do Kalwarii Zebrzydowskiej z okolic Sląska. W latach 1735 i 1739 zanotowano tu dwa nawrócenia z luteranizmu na katolicyzm ${ }^{158}$.

Jako przykład kultu i pielgrzymek lokalnych może posłużyć kościół w Sulisławicach, gdzie czczono obraz Matki Bożej, który uważano za cudowny. Kroniki parafialne w Sulisławicach zanotowały w latach: 1736, 1739, 1741, 1743, 1745 i 1746 opisy cudownych uzdrowień. Można z tych zapisków wnioskować, że wieść o tych cudach docierała do wiernych w okolicznych miejscowościach i powodowała liczne pielgrzymki do Sulisławic, przynajmniej z najbliższych okolic ${ }^{159}$.

DAS SAKRAMENTALE UND PARALITURGISCHE LEBEN IN DER DIOZESE KRAKOW IN DER ZEIT DES EPISKOPATS DES KARDINALS JOHANN LIPSKI (1732-1746)

\section{Zus a m me n a s s ung}

Die vorliegende Bearbeitung behandelt das religiöse Leben in den Pharrgemeinden der Diözese Kraków während des 14-jähringen Episkopats des Bischofs J. A. Lipski. Das Spenden der heiligen Sakramente, liturgische Handlungen und andere Andachten wurden in dieser Zeit nach den Vorschriften der Synoden der Kirchenprovinz Gniezno abgehalten, zu der die Diözese Kraków zugeordnet war, und gemäss den Weisungen des Bischofs Lipski.

Die Taufe wurde von den Priestern in den Pfarrkirchen am ersten Tage nach der Geburt des Kindes erteilt, im Falle der Todesgefahr zu jeder Tages- und Nachtstunde. Die bei der Geburt des Kindes anwesenden Personen waren über die Erteilung der Taufe im Notfalle belehrt. Das Geburtsdatum des Kindes war gewöhnlich entscheidend für die Zuteilung des Taufnamens. Die Priester sorgten

158 Archiw. Prow. OO. Bernardynów w Krakowie: Historia Calvariae [...] A. D. 1613, s. 187; Historia Calvariae [...] 1590-1909, s. 764.

$159 \mathrm{~J}$. W iśniewski, Monografia dekanatu sandomierskiego, Radom 1915, s. 275 (Sulisławice). 
gewissenhaft, dass alle Kinder getauft werden. Die Taufbecken wurden geschmückt, das Taufwasser und die heiligen Ole eifrig verwahrt. Die Taufen wurden in Taufbüchern niedergeschrieben.

Das Sakrament der Firmung wurde von Bischof Lipski oder seinem Koadjutor Michael Kunicki erteilt, aus Anlass der Kirchenkonsekration, der bischöflichen Visitation der Pfarrgemeinde oder der Missionsandachten. Aus der kleinen Zahl der Gefirmten und auch aus den Eintragungen nach den bischöflichen Visitationen darf man schliessen, dass sowohl die Bischöfe, als auch die Pfarrer und Gläubigen wenig Verständnis für den Wert dieses Sakramentes hatten.

Bischof Lipski legte grossen Wert auf die Bedeutung der heiligen Messe im Leben der Gläubigen. Er empfahl die Messe an allen Sonn- und Feiertagen abzuhalten und dies zu einer für die Gläubigen gelegenen Stunde. Er forderte Verehrung zu bezeigen für das allerheiligste Altarsakrament und für die Heiligkeit des eucharistischen Opfers. Die Hauptmesse (genannt "suma” - Hochamt) wurde meistens um zehn Uhr gefeiert. In der Mehrzahl der Pfarrgemeinden wurde das Messopfer an Sonn- und Feiertagen würdig abgehalten, die Gläubigen nahmen daran gerne teil.

Das Altarsakrament wurde in einem verschlossenen und schön ausgestattenen Tabernakel auf dem Hochaltar verwahrt. In manchen Kirchen brannte vor dem Tabernakel ein „ewiges” Licht. Mit der heiligen Messe war der Empfang der heiligen Kommunion verbunden. Die Pfarrer sorgten, dass die Gläubigen in der Osterzeit pflichtmässig die Kommunion empfingen. Auch Ablasstage der Pfarrgemeinde und der religiösen Bruderschaften gaben Gelegenheit zum Kommunionempfang. In den Kirchen bereicherten das religiöse Leben der Gläubigen Andachten, Ablässe, Prozessionen; in Privathäusern das Morgen- und Abendgebet. Mit dem Gebet verband man fromme Übungen, von denen vor allem das Fasten.

Das Spenden des Sakramentes der Busse betrachteten Bischof Lipski und die Seelsorger als die wichtigste Pflicht der Seelsorge. Eingesetzte Examinatoren erteilten den Priestern die Ermächtigung zum Beichtehören der Gläubigen. Die Priester beichteten besonders in der Fasten- und Osterzeit, auch in Tagen der Ablässe und der Exerzitien in den Pfarreien.

Den Anordnungen des Rituals von Piotrków gemäss sorgten die Seelsorger, dass die Kranken vor dem Tode die heiligen Sakramente erhielten. Die Diözesanbehörde richtete strenge Aufmerksamkeit auf die Vernachlässigungen dieser Pflicht, Priester, die den Besuch der Kranken verweigerten, wurden vom Kirchengericht bestraft. Oft geschah es so, dass die Kranken beichteten und die heilige Wegzehrung empfingen, aber seltener um das Sakrament der Krankenölung baten.

Kandidaten des geistlichen Standes wurden im Priesterseminar auf das Sakrament der Priesterweihe vorbereitet. Die Priesterweihe wurde von Bischof Lipski, oder auch von anderen in der Diözese weilenden Bischöfen erteilt. Ort der Weihe war die Domkirche am Wawel, Zeit der Weihe gewöhnlich Quatembertage oder der Samstag vor dem Passionssonntag.

Das Sakrament der Ehe besass mit Rücksicht auf seinen sozialen Charakter eine wichtige Stelle im religiösen Leben der Diözese. Vor der Ausrufung der Aufgebote fragten die Seelsorger die Brautleute einzeln um ihre Einwilligung, um mögliche Ehehindernisse, verlangten von ihnen die Erklärung, dass sie niemand anderem eine Ehe versprochen haben und dass ihre Eltern mit der Ehe einverstanden sind. Die Aufgebote wurden an drei folgenden Sonntagen, resp. Feiertagen verlautbart. Die Ehe segnete der zugehörige Pfarrer in der Pfarrkirche. Die kirchlich vorgeschriebene Zeit der Eheschliessungen wurde streng eingehalten. 
Die Sakramentalien bereicherten und ergänzten das religiöse Leben der Gläubigen. Es wurden geweiht: Salz, Wasser, Wein, Hafer, Gold, Weihrauch, Myrrhe, Kerzen, Palmzweige, Fiver, Essiswaren, Kräuter an den im kirchlichen Ritualbuch vorgesehenen Tagen. Eine besondere Stelle hatte die Weihe der Häuser, der Wohnungen, in der Weihnachtszeit, die sogenannte „Kolende”. Von Segnungen wurden am öftesten erteilt: das Segnen der Braut nach der Eheschliessung und das Segnen der Mutter nach der Geburt des Kindes. Die Gläubigen legten auch grossen Wert auf die Beerdigungszeremonien. Die Toten wurden neben den Pfarrkirchen begraben, die Zeremonien zelebrierte der Pfarrer. In einer Ordenskirche konnte die Beerdigung mit der Zustimmung des Pfarrers stattfinden. Begräbnisse wohlhabender Gläubigen wurden oft prunkvoll gefeiert und dauerten mehrere Tage.

Aus Anlass der geistlichen Dienste erstatteten die Gläubigen Opfer zum Unterhalt des Klerus. Bischof Lipski erliess Vorschriften, welche die Höhe dieser Opfer regelten. Verehrung der Heiligen, Pilgerfahrten zu Gnadenbildern, waren weitere Erscheinungen religiösen Lebens der Diözese. Die grösste Verehrung zollten die Gläubigen der seligsten Jungfrau Maria - an sieben Feiertagen im Jahr. Zu den beliebtesten Heiligen zählten: Johannes der Täufer, der hl. Joseph, Peter, Paul, Stephan, Laurentius, die heiligen Frauen Agnes, Anna, Maria Magdalene, Katharina. Von polnischen Heiligen wurde verehrt vor allem der hl. Stanislaus, Bischof und Märtyrer.

Der Heiligenkult äusserte sich besonders in der Verehrung von Gnadenbildern und Figuren, was zu Pilgerfahrten führte. Am öftesten und zahlreichsten wurden Wallfahrten nach Częstochowa und Kalwaria veranstaltet, doch hatte auch jede Gegend ihre kleineren Kultstätten, zu denen die Gläubigen pilgerten, um dort zu beten. Die Pilger opferten Weihgeschenke, mit welchen sie Bilder und Figuren schmückten. 